Working Papers No. 111/08

\title{
A Stakeholder Empire: The Political Economy of Spanish Imperial Rule In America
}

\author{
Regina Grafe \\ $\&$ \\ Alejandra Irigoin
}

(C) Regina Grafe, Northwestern University

\& Alejandra Irigoin

College of New Jersey 
Department of Economic History London School of Economics Houghton Street London, WC2A 2AE

Tel: $\quad$ +44 (0) 2079557860

Fax: $\quad$ +44 (0) 2079557730 


\section{A Stakeholder Empire: The Political Economy of Spanish Imperial Rule in America*}

Regina Grafe and Alejandra Irigoin

This paper revises the traditional view of Spain as a predatory colonial state that extracted revenue from natural resources and populations in the Americas while offering little in return. Using $18^{\text {th }}$ century Spanish American treasury accounts we show that local elites not only exerted important control over revenue collection as argued by (Irigoin/Grafe 2006) but also over expenditure allocation. Mirroring Elliot's characterization of the English empire as a 'stakeholder empire' we contend that the Spanish colonial state developed into a stakeholder model, in which local interests were deeply invested in the survival and expansion of empire. The means of co-optation were intra-colonial transfers, as well as credit relations between the state and colonial individuals and corporations, which guaranteed that much of colonial revenue was immediately fed back into the local economy, while minimizing enforcements costs. By allowing stakeholder control of both revenue and expenditure Spain managed to avoid the problems faced by France where royal control of expenditure clashed with at least partial elite control of revenue raising (Velde/Weir 1992, Hoffman/Rosenthal 1997).

Once upon a time early modern Spain was used as the picture postcard case of a predatory colonial state that extracted revenue from plentiful natural resources and populations in the Spanish Indies; an empire that centralised governance and suppressed colonial desires for political participation, claiming absolutist control for the Crown in Madrid. ${ }^{1}$

\footnotetext{
* The authors would like to thank Guillaume Daudin, Joel Felix, Cristina Mazzeo, Frank Safford, Guillermina del Valle Pavon and Bartolome Yun as well as participants of the conference 'The Rise and Decline of Imperial Leadership Conference' at Northwestern University, the workshop 'Local Institutions, Market and Economic Development in the Mediterranean World, 1500-1900' at the European University Institute, Florence and the $2^{\text {nd }}$ European Congress in World and Global History in Dresden for comments and criticisms. We would also like to acknowledge excellent research assistance provided by Nicole Pitella and financial support from The College of New Jersey.

${ }^{1}$ See e.g.Douglass C. North and Robert P. Thomas, The Rise of the Western World: A New Economic History (Cambridge: Cambridge University Press, 1973).; Douglass C.
} 
This description has long been attacked by historians, and the critique has more recently been taken up by some economic historians. ${ }^{2}$ The predictions of the model of Spanish colonialism as a strong, absolutist, centralist, predatory, extractive and wasteful political beast clash strongly with the evidence derived from the fiscal system, which linked rulers and subjects. ${ }^{3}$ The Empire operated in its dealings with the constituent parts of its monarquia into the $19^{\text {th }}$ century in a way that resembled a conglomerate of relatively independent territorial units not a 'modern' nation state.

Yet, even more recent - and more historically informed - portraits of Colonial Spanish America largely define what this Empire was not. In his thorough comparison of the empires in the Atlantic world, Elliott presents the distinct nature of colonial government in British America as "allow(ing) more scope for the independent exercise of political power. This was a society whose political and administrative institutions were more likely to evolve from below than to be imposed from above. It was also a society that operated in a political culture more effectively grounded in notions of representations than the political culture transferred to America from

North, "Institutions and Economic Growth: An Historical Introduction," World Development 17, no. 9 (1989)..Douglass C. North, Barry R. Weingast, and W. Summerhill, "Order, Disorder and Economic Change. Latin America Verus North America," in Governing for Prosperity, ed. B. Bueno de Mesquita and H.L. Root (New Haven: 2000). Daron Acemoglu, Simon Johnson, and James Robinson, "The Colonial Origins of Comparative Development: An Empirical Investigation," American Economic Review 91 (2001), Daron Acemoglu, Simon Johnson, and James Robinson, "Reversal of Fortune: Geography and Institutions in the Making of the Modern World Income Distribution," Quarterly Journal of Economics (2002), James Mahoney, "Long-Run Development and the Legacy of Colonialism in Spanish America," American Journal of Sociology 109, no. 1 (2003).

2 John H. Coatsworth, "Political Economy and Economic Organization," in The Cambridge History of Latin America. Vol1: The Colonial Era and the Short Nineteenth Century, ed. Victor Bulmer-Thomas, John H. Coatsworth, and Roberto Cortès-Conde (Cambridge: Cambridge University Press, 2006), Maria Alejandra Irigoin and Regina Grafe, "Bargaining for Absolutism. A Spanish Path to Empire and Nation Building," Hispanic American Historical Review, no. 2 (2008).

${ }^{3}$ Regina Grafe and Maria Alejandra Irigoin, "The Spanish Empire and Its Legacy: Fiscal Re-Distribution and Political Conflict in Colonial and Post-Colonial Spanish America," Journal of Global History 1, no. 2 (2006). 
Castile". ${ }^{4}$ According to Elliott this representation took its institutional shape in form of territorial assemblies. He claims that this pattern of representation emerged in the Anglo-colonies "partly because voting was an established feature of joint stock companies and was therefore likely to be transferred with relative ease to colonial settlements operating under company charters". ${ }^{5}$ One can push the argument a little further: Rooted as it was in a particular kind of commercial expansion, the British American political economic scheme of representation and governance came to resemble something that we might call a 'shareholder society and empire'.

In this paper we propose to use Elliott's characterization of the British Empire in North America to conceptualize the rule of imperial Spain in the New World by framing the political economic nature of the Spanish empire as a 'stakeholder empire' in contrast to the British American shareholder empire. We propose to outline the nature of such a stakeholder empire by studying how and on what the royal treasuries in Spanish America spent their taxes, or in other words, how subjects became stakeholders and how stakeholders interacted with and were represented in the management / governance of the empire. We analyse the size and composition of expenditure as well as the institutional arrangements that were employed to decide over and affect spending. For the former we employ data on the expenditure of Spanish American treasuries, so-called cajas, collected by the seminal work by TePaske and

\footnotetext{
${ }^{4}$ John H. Elliott, Empires of the Atlantic World. Britain and Spain in America, 14921930 (New Haven and London: Yale University Press, 2006), p.134. See also William R. Summerhill, "Fiscal Bargains, Political Institutions and Economic Performance," Hispanic American Historical Review 88, no. 2 (2008).

${ }^{5}$ Elliott, Empires, p.135. Thus, a "governor, as a chief colonial executive" introduced by Elliott resembles the CEO of a shareholder company of today. Elliott, Empires, p. 136.
} 
Klein, which we reclassified entirely for three selected five-year periods, 1729-1733, 1785-89 and 1796-1800. ${ }^{6}$ (See Appendix).

To our knowledge this is the first systematic exploration of the actual ends and purposes of the monies defrayed by the royal treasuries, so section I makes the case for the main point of this paper: a revision of the political economic nature of the Spanish empire. Section II considers the size of the state, approximated by the share of GDP appropriated as taxes. GDP figures for the region are not very robust, but we can provide upper and lower bounds based on the best available estimates and offer a comparison with peninsular Spain, France and England. Section III explores the structure of the royal expenditure in the colonies and emphasises the role of intra-colonial transfers (ICTs), one of the main features of Spanish rule in the new world. ${ }^{7}$ Section IV scrutinizes the composition and sectoral distribution of colonial spending. It highlights the channels through which the bulk of revenues collected in the empire remained within the region, and how they were ploughed back into the colonial economy. Section $\mathrm{V}$ explores some features of Spanish imperial spending in more detail and revises the weight and characteristics of the main fiscal branches of the early modern empires: defence and financial expenditure. Finally some conclusions are offered.

\section{!}

Up to now, the core arguments for discarding the traditional model of Spanish imperial rule have come from a careful examination of crown revenues in the colonies as an indicator of the performance of the

\footnotetext{
${ }^{6}$ Herbert S. Klein and John Jay TePaske, Las Cajas De La Real Hacienda De La América Española, 1528-1820 (Mexico City: UNAM Facultad de Economía, 2004).

${ }^{7}$ Grafe and Irigoin, "Legacy."
} 
imperial state. ${ }^{8}$ Contrary to the traditional narrative, Spanish imperial revenue collection was de-centralised and jurisdictionally fragmented into a large number of tax raising authorities (so-called cajas) and a variety of tax payers differentiated by status, ethnicity, corporate bodies or individuals, urban/rural residence and geographical demarcation. This created considerable possibilities for local colonial players to shape rates, incidence and collection reflected, for example, in the uneven application of allegedly universal taxes such as the alcabalas (the sales tax) or the quinto (tax on silver mining). Although royal revenues extracted from America to Spain formed a substantial share of the total receipts of the Madrid hacienda (rising to about 13 percent in the later $18^{\text {th }}$ century), they were actually a notably smaller share of revenue collected in America, which fell from 11 percent (1729-33) to 4.8 (1785-89) rising slightly to 5.2 (1796-1800). ${ }^{9}$ Nor did the colonial treasuries lean very heavily on the

\footnotetext{
${ }^{8}$ This discussion follows closely Ibid. and Irigoin and Grafe, "Bargaining for Absolutism."

${ }^{9}$ Estimate of share of colonial hacienda based on data described in Appendix 1. Estimate of share of Spanish hacienda based on average for 1763-1800 Indias revenue as share of total revenue minus carry-overs, using José Patricio Merino Navarro, Las Cuentas De La Administración Central Española, 1750-1820 (Madrid: Instituto de Estudios Fiscales, 1987), 'Cargos al Tesorero General'. Using the same source Marichal has implied a significantly larger share for the American contribution to the Spanish treasury (14-17 percent) by comparing transfers resulting from ordinary and extraordinary American revenue to peninsular ordinary revenue only. Unfortunately neither the original Spanish edition (Marichal 1999) nor the English edition (Marichal 2007) explain which parts of revenue are considered ordinary and the definition seems to have been adjusted by the author since the values do not coincide in the two editions. The exclusion of peninsular extraordinary revenue creates the somewhat misleading impression that the metropolis was extracting additional revenue from the Americas only. Extraordinary revenue in the peninsula rose equally fast as the contribution from the Indies. The Empire under strain put pressure on all constituent parts of the monarchy using similar means almost everywhere. Carlos Marichal, $\mathrm{La}$ Bancarrota Del Virreinato: Nueva España Y La Las Finanzas Del Imperio Español 1780-1810 (Mexico: Fondo de cultura económica, 1999), Appendix 1. and Carlos Marichal, Bankruptcy of Empire. Mexican Silver and the Wars between Spain, Britain and France, 1760-1810 (Cambridge: Cambridge University Press, 2007), Appendix 1. See also Elliott, Empires, p.95. Jacques A. Barbier and Herbert S. Klein, "Revolutionary Wars and Public Finances: The Madrid Treasury, 1784-1807," Journal of Economic History 41, no. 2 (1981): table 1B p.338.. Yun Casalilla estimates the American contribution to the Crown's income in the $17^{\text {th }}$ century in less than 10 percent. Bartolomé Yun Casalilla, "The American Empire and the Spanish Economy: An
} 
famous silver mining sector for revenue collection. Instead, especially in the late colonial period, domestic trade and consumption were favourite targets of the imperial revenue collection machinery. ${ }^{10}$

Overall there is plenty of evidence for a vast amount of autonomy in the workings of the colonial treasury districts, which relied on negotiation at the local, regional and with the central level. Fiscal functions were often 'privatised' in a pattern that had strong peninsular precedents. Most importantly, a very large share of Spanish American revenues was not spent in the same regions, in which they were collected. ICTs were until recently a much ignored and ill-understood but very important feature of the Spanish American colonial system. ${ }^{11}$ For one in four of the 72 colonial treasury districts that existed towards the late $18^{\text {th }}$ century in mainland Spanish America, funds transferred from other cajas were the single largest source of revenue. The empire in Spanish America financed itself through a network of interdependent treasury districts related in a large and complicated web of intra-colonial transfers. ${ }^{12}$ In other words, the Spanish Empire was self-financing throughout, while continuing to expand territorially. And since much of the actual transfer activity was privatised too, this system was sustained by the co-optation of regional mercantile

Institutional and Regional Perspective," Revista de Historia Económica XVI, no. 1 (1998): p.139.

${ }^{10}$ Grafe and Irigoin, "Legacy," pp.255-257. Absolutist Spain like parliamentary England and unlike absolutist France relied strongly on indirect taxation, customs and alcabalas, sisas (internal trade and consumption taxes). For France and Britain see Peter Mathias and Patrick Karl O'Brien, "Taxation in England and France, 1715-1810," Journal of European Economic History 5 (1976): 338.

${ }^{11}$ The notable exception is Carlos Marichal and Matilde Souto Mantecón, "Silver and Situados: New Spain and the Financing of the Spanish Empire in the Caribbean in the Eighteenth Century," Hispanic American Historical Review 74, no. 4 (1994).

12 'Border' areas in northern Mexico and southern Chile were the exceptional regions where the Crown undertook some direct investments on defence. "Subsidies came in from branches of government based in more central areas, channelled to individuals on the scene through the frontier institutions, so that the latter were able to play on a small scale the usual role of cites as market of goods and labour." James Lockhart and Stuart Schwartz, Early Latin America. A History of Colonial Spanish America and Brazil (Cambridge: Cambridge University Press, 1983), p.289. 
elites, which benefited greatly from the use of fiscal monies as short-term ready-to-invest capital. ${ }^{13}$

The study of revenue collection in the Spanish colonies has thus challenged the absolutist caricature of Spanish rule and opened up new debates about the interpretation of comparative imperial structures. However, it could rightly be argued that a fundamental part of the analysis of the link between ruler and subject in these comparisons is so far missing, namely the question of 'what the Empire actually spent its money on?' Overall economic historians have looked in much more detail at the revenue side of early modern empires and states than at the expenditure side. ${ }^{14}$ This is partially driven by the fact that researchers concentrated on using fiscal accounts as proxies for the performance of the economy rather than as a measure of the performance of the state as we do. It is also a consequence of a basic underlying assumption that the main purpose of early modern tax collection was defence spending. Robert's influential claim was that starting in the $16^{\text {th }}$ century a military revolution in strategy and technology left European states with little alternatives. They had to reform their fiscal systems if they wanted to survive in a phase of interstate 'mergers and acquisition', that saw at least three out of four states disappear for good. ${ }^{15}$ There is little doubt that despite some criticisms this concept contains a fundamental truth. Yet, as we will argue below, there were nevertheless large differences in what Empires spent their revenues on and most importantly, how they disbursed their

\footnotetext{
${ }^{13}$ Irigoin and Grafe, "Bargaining for Absolutism," pp.193ff.

14 José Jurado Sánchez, El Gasto De La Hacienda Española Durante El Siglo Xviii. Cuantía Y Estructura De Los Pagos Del Estado (1703-1800) (Madrid: Instituto de Estudios Fiscales, 2006), p.16.

${ }^{15}$ Michael Roberts, The Military Revolution, 1560-1660; an Inaugural Lecture Delivered before the Queen's University of Belfast ([Belfast: M. Boyd, 1956). Geoffrey Parker, The Military Revolution: Military Innovation and the Rise of the West, 1500-1800 (Cambridge: 1988). Charles Tilly, Coercion, Capital and European States, Ad 990-1990 (Cambridge: 1990). and Edgar Kiser and April Linton, "Determinants of the Growth of the State: War and Taxation in Early Modern France and England," Social Forces 80, no. 2 (2001).
} 
payments. And we argue that these differences tell us a lot about the nature of the state.

Finally, economic historians' strong concentration on the revenue side of fiscal accounts is also rooted in an ex-ante ideological conviction that the relationship between state and subject was one of state predation versus subjects' attempts to evade and avoid taxation. Thus, in so-called absolutist regimes like Spain the agency of colonial subjects is seen as confined to tax avoidance, evasion or smuggling as means to overcome ruler's heavy-handedness. Corruption and poor compliance of individual colonial subjects, and collusion among the crown and corporate bodies in the colonies are stressed as rational responses of imperial subjects and institutions vis a vis the absolutist predatory ruler. The assumed rather than proven lack of representation in this political economic arrangement is cited regularly as the ultimate cause for Spanish peninsular and colonial decline. This notion has distracted historical economists from the equally important question how subjects actually engaged with the colonial state, bearing in mind the remarkable lack of challenges from within to the persistence of Spanish rule.

Recent research on colonial revenue collection and tax incidence has entailed a rethinking of the traditional story of the predatory state by showing that colonial subjects had a lot more influence on who was taxed how much than hitherto assumed. Yet, that is only one side of the coin. Whether they were shareholders or stakeholders, colonial subjects like every other taxpayer expected a return on their investment in the colonial state. In order to understand the long-term survival of Spanish imperial rule, which is so counter-intuitive to current thinking in political economy, it is equally important to find out whom colonial expenditures benefited in which way. 


\section{II}

\section{How Big Was The Spanish State?}

Before we turn to the analysis of expenditure, however, we would like to place the Spanish Empire in an international comparison regarding the size of the state. The traditional picture of the strong and extractive Spanish state always implied that this was a 'big' but 'inefficient' state though actual estimates of its share in total GDP were not offered. Standard political economy models divide early modern states into those that are absolutist and those where rulers are limited by constitutions (essentially England after 1688) or those that were run by princes vs. those run (indirectly) by merchants. ${ }^{16}$ Absolutist autocrats are seen as predators that used their unlimited power to overtax, expropriate and prey on their own subjects. By contrast, rulers constitutionally constrained by parliament can tax efficiently because they can credibly commit to reliable rules of taxation rather than arbitrary exactions. Since they enjoy credibility with the markets they can raise loans at favourable interest rates lowering the burden on the tax payer and creating a virtuous cycle of financial market development and sound fiscal regimes that foster growth.

\footnotetext{
${ }^{16}$ Brad De Long and Andrei Shleifer, "Princes or Merchants. European City Growth before the Industrial Revolution," Journal of Law and Economics 36 (1983), Douglas C. North and Barry R. Weingast, "Constitutions and Commitment: The Evolution of Institutions Governing Public Choice in Seventeenth-Century England," Journal of Economic History XLIX, no. 4 (1989).
} 
Table 1 Tax Share of GDP, late $18^{\text {th }}$-Century

\begin{tabular}{l|llllll}
\hline & $\begin{array}{l}\text { \% of GDP } \\
\text { appropriated as } \\
\text { taxes (1785- } \\
\text { 89) }\end{array}$ & $\begin{array}{l}\text { Source } \\
\text { revenue }\end{array}$ & $\begin{array}{l}\text { source } \\
\text { GDP }\end{array}$ & $\begin{array}{l}\text { \% of GDP } \\
\text { appropriated } \\
\text { as taxes } \\
(1785-89)\end{array}$ & $\begin{array}{l}\text { source } \\
\text { revenue }\end{array}$ & $\begin{array}{l}\text { source } \\
\text { GDP }\end{array}$ \\
\hline New & 14.5 & $1)$ & 2) \& 3) & 22.0 & $1)$ & $7)$ \& 8) \\
Spain & & & & & & $4)$ \\
Peru & 26.2 & $1)$ & $4)$ & 5.7 & $4)$ \\
Chile & 4.7 & $1)$ & $4)$ & 10.1 & $4)$ & $4)$ \\
River & 11.3 & $1)$ & $4)$ & 4.2 & $4)$ & $4)$ \\
Plate & & & & & & \\
Britain & $(1785-90) 12.3$ & $5)$ & $5)$ & & & \\
Britain & $(1810-15) 18.2$ & $5)$ & $5)$ & & & \\
Spain & $(1800) 10.5$ & $9)$ & $6)$ & & & \\
France & $(1788) 11.6$ & $10)$ & $11)$ & & & \\
\hline
\end{tabular}

Source: 1) our estimates based on reclassified cajas; 2) Coatsworth 1990; 3) TePaske (1985); 4) Coatsworth (1998); 5) O'Brien (1988); 6) Carreras (2003); 7) Aubrey (1950); 8) Rozenzweig (1963) 9) own estimates based on Merino Navarro (1987) ten year average 1790 to 1800 and Hamilton (1947), 10) Weir (1989) and 11) Daudin (2005) p. $18-9$

Table 1 Column 2 shows the size of the colonial and European state as the tax over GDP ratio in the later 1700 s based on our own reestimation of the regional revenues using available GDP estimates by Coatsworth. Estimates range from 5 percent for Chile to 26 percent for Peru. Column 5 re-estimates the same ratio using alternative estimates of revenue and, where available, GDP. Here the shares are between 4 percent for the River Plate and 22 percent for New Spain. ${ }^{17}$ The margins of error are so large because of the difficulties in making inter-regional comparisons based on back extrapolated aggregates for political units that came into existence only after the 1820s.

\footnotetext{
${ }^{17}$ The large margin of error in the figures comes from the GDP estimates rather than revenues.
} 
However, these very tentative figures do suggest, that the total fiscal burden in colonial Spanish America was probably not outside the range O'Brien estimated for the fiscal role model of the $18^{\text {th }}$ century, Britain: between 12 percent in peace and 18 percent in war. Based on our estimates the tax take relative to GDP was higher in both Britain and some of the Spanish colonies than in peninsular Spain or pre-revolution France. As several historians have argued convincingly, the British state was very successful at extracting taxes from its subjects and the British total fiscal burden per capita was higher than that of France or Spain. ${ }^{18}$ But if the comparison is extended beyond the core European competitors, to include e.g. the Ottoman Empire, Spain looks more like France and England overall than like the Ottoman Empire which never appropriated more than 6 percent of GDP in the form of taxes. ${ }^{19}$

Notwithstanding the large margins of errors contained in table 1, we conclude that Spanish rule in both, the Peninsula and the colonies, was not significantly different from its main European competitors in terms of the tax over GDP ratio. This would support the view that 'absolutist' rulers were actually subject to limitations of their fiscal power that were de-facto not unlike a constitutional monarchy. As Rosenthal has argued for the case of France so-called absolutist rulers did not control revenue collection thanks to the constitutional structure of a composite state that consisted of many territories and corporate bodies, which retained their own constitutional structures rather than merge into a unified administration creating complex systems of stakeholders. Indeed, Epstein

\footnotetext{
${ }^{18}$ P.K. O'Brien, "The Political Economy of British Taxation, 1660-1815," Economic History Review, 2nd ser. (1988). Mathias and O'Brien, "Taxation.", Philip Hoffman and Kathryn Norberg, Fiscal Crises, Liberty, and Representative Government (Stanford: Stanford University Press, 1994). Jean-Laurent Rosenthal, "The Political Economy of Absolutism Reconsidered," in Analytic Narratives, ed. Robert Bates and et al. (Princeton: Princeton University Press, 1998), p.73.

19 Sevket Pamuk, "Ottoman State Finances and Fiscal Institutions in European Perspective, 1500-1800," paper presented at the Northwestern Seminar in Economic History (2007).
} 
and more recently Dincecco have shown that pre 1800 , the main limitation on European states to tax was not rooted in their constitutional structure but in their degree of jurisdictional fragmentation. ${ }^{20}$

The notable feature of Spanish taxation was therefore not its size but that the tax incidence differed greatly between distinct parts of the Empire. Given that there were multiple centres of decision making regarding revenue collection this should not surprise. There is e.g. some tentative evidence that Spanish American treasury districts that were beneficiaries of ICTs enjoyed a lower per capita tax rate. This became painfully clear to the beneficiaries of ICTs when Independence wars interrupted the flow of money. In 1817, after Mexican remittances to Cuba (situado) had ceased, the tax payments of free Cubans rose to 8.71 pesos per capita from 5.54 pesos in 1792 and 4.17 pesos in $1774^{21}$.

The structure of the Spanish peninsular and colonial revenue system suggests that wondering about the relative 'strength' and 'weakness' of the state with regard to its taxing ability might simply be the wrong question. De-centralised fiscal states like Spain could not be strong enforcers of public property rights to taxation. Yet, it stands also to reason that economic historians have mistaken means for ends when they assume that fiscal strength was the ultimate aim of early modern rulers. Recent analyses of Spanish revenues in the colonies and the metropolis argue that the utility function of the Spanish Crown was instead the aggrandisement of the empire and survival of its rule at the lowest

\footnotetext{
${ }^{20}$ Stefan R. Epstein, Freedom and Growth: The Rise of States and Markets in Europe, 1300-1750 (London: Routledge, 2000). and Mark Dincecco, "Fiscal Centralization, Limited Government, and Public Revenues in Europe, 1650-1913," (Lucca: Lucca Institute for Advanced Studies, 2007). Rosenthal, "Political Economy." and Philip T. Hoffman and Jean-Laurent Rosenthal, "The Political Economy of Warfare and Taxation in Early Modern Europe: Historical Lessons for Economic Development," in The Frontiers of the New Institutional Economics, ed. John N. Drobak and John V.C. Nye (San Diego et al.: Academic Press, 1997).

${ }^{21}$ Grafe and Irigoin, "Legacy." 258-259. Irigoin and Grafe, "Bargaining for Absolutism," p.197.
} 
possible costs. ${ }^{22}$ This did depend in part on being able to raise the fiscal resources to run and protect the Empire. Yet, it had to be done without incurring excessive fiscal and political costs. Often colonial regional resources were not directly taxed in an attempt to co-opt regional colonial elites. Survival of Empire was bought at the expense of liquid resources available to the treasury. Sometimes, less was more.

\section{III}

Intra-Colonial Transfers and Transfers to the Metropolis.

As argued above there is a serious lack of analysis of what European Empires in general and the Spanish Empire in particular spent their revenues on. Table 2 and figure 1 below give some first answers to this question for the Spanish Empire in the $18^{\text {th }}$ century based on our reworking of the published colonial Spanish treasury accounts. Table 2 illustrates the enormous expansion of expenditure over the course of the $18^{\text {th }}$ century from roughly 10 million pesos per annum in the early $1730 \mathrm{~s}$ to over 40 million in the late 1780 s and 70 million in the late 1790 s. This expansion went along with an important trend regarding the share of net expenditure actually transferred from the colonial treasuries to Spain. These fell from an average of about 12 percent per annum in the first five year period to five percent in the second and just under 4 in the last (see Appendix Table 9). In other words, while the total amounts shipped from the colonies to Spain undoubtedly increased, they constituted a modest share of total expenditure at the beginning of the $18^{\text {th }}$ century and a marginal one at the end. The Spanish Empire was not an extractive machinery geared towards siphoning off American resources towards the

\footnotetext{
${ }^{22}$ Maria Alejandra Irigoin and Regina Grafe, "Response to Carlos Marichal and William Summerhill," Hispanic American Historical Review, no. 2 (2008): 243.
} 
metropolis, even at this time of maximum fiscal strain from the wars in Europe.

Table 2 Intra-Colonial Transfers (ICTs) and Transfers to Spain as Share of Total Net Expenditure 1729-1800 (\%), all Available Treasury Districts

\begin{tabular}{l|lrrr}
\hline & net expenditure (pesos) & $\begin{array}{r}\text { ICTs } \\
(\%)\end{array}$ & $\begin{array}{r}\text { To Spain } \\
(\%)\end{array}$ & $\begin{array}{r}\text { no of } \\
\text { treasuries }\end{array}$ \\
\hline 1729 & $8,057,311$ & 34 & 5.0 & \\
1730 & $11,253,542$ & 28 & 12.8 & \\
1731 & $8,924,902$ & 28 & 1.6 & \\
1732 & $11,218,904$ & 17 & 16.4 & \\
1733 & $12,690,660$ & 28 & 13.6 & 35 \\
& & & & \\
1785 & $41,167,891$ & 37 & 7.5 & \\
1786 & $47,014,076$ & 48 & 0.4 & \\
1787 & $49,933,057$ & 31 & 0.0 & \\
1788 & $40,695,433$ & 48 & 8.1 & \\
1789 & $42,006,554$ & 46 & 8.8 & 72 \\
& & & & \\
1796 & $63,099,930$ & 44 & 11.2 & \\
1797 & $69,358,934$ & 35 & 0.0 & \\
1798 & $89,045,083$ & 28 & 6.7 & \\
1799 & $88,403,387$ & 34 & 0.0 & \\
1800 & $74,610,075$ & 29 & 0.6 & 72 \\
\hline
\end{tabular}

Source: See Appendix

Figure 1 Intra-Colonial Transfers (ICTs) and Transfers to Spain as Share of Total Net Expenditure 1729-1800 (\%)

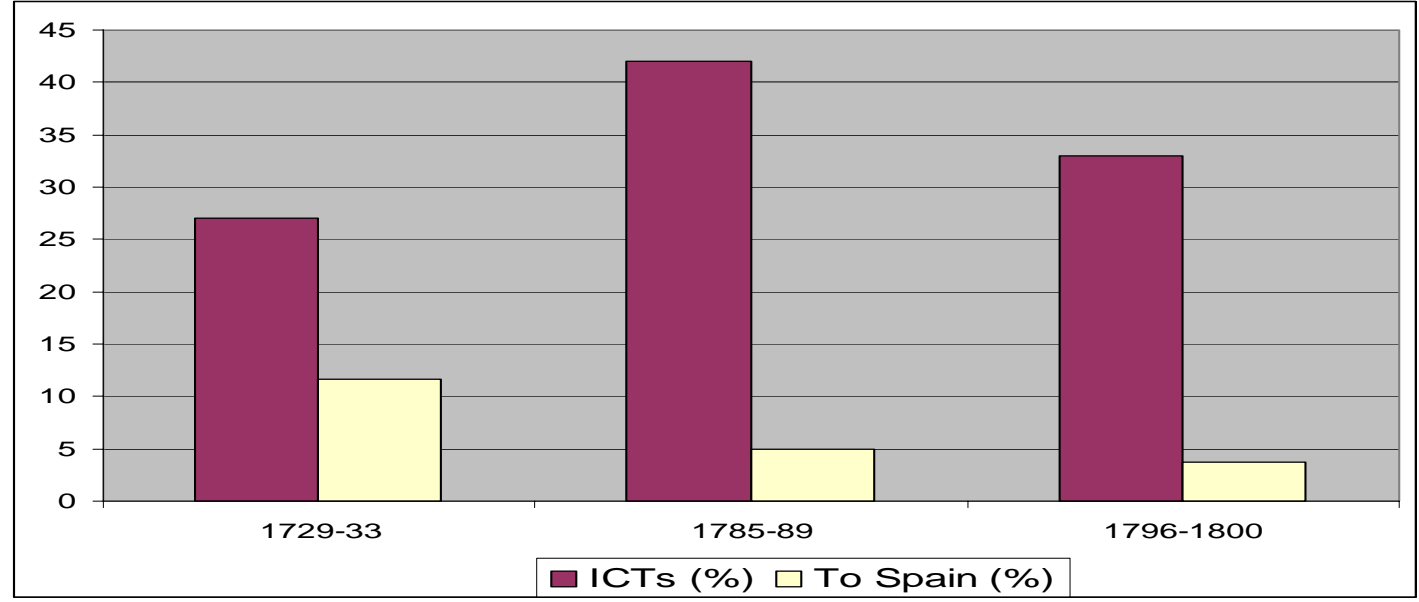

Source: See Appendix 
Much more important than transfers to Spain were ICTs. In terms of the overall share of expenditure going to ICTs we observe no clear trend over the $18^{\text {th }}$ century (see figure 1 ). Throughout our three samples containing fifteen years of data they accounted for between 17 and 48 percent of overall net expenditure. In total about one third of all monies were thus not spent in the caja where they was raised. When we break this down further we see, however, that there are some differences over time. In the 1730 s, the average amount going to ICTs across all cajas was higher than the average share of total expenditure spent on ICTs (51 v 27 percent, see table 3 below). This is because in the early eighteenth century a large number of often small cajas transferred almost all of their revenue into a few big cajas (see Appendix Table 9), which in turn realised most disbursements. In the latter part of the century this pattern had all but disappeared. By the 1780s the total number of treasury districts within the same territory had more than doubled from 35 to 72 (see table 2 and Appendix table 9). This regional decentralization of the fiscal machinery shows no clear patterns in the flow of transfers. Small or large cajas might be net beneficiaries of - or payers into - the system; some performed as intermediaries and the direction and flow might change from year to year. ${ }^{23}$ The empire became even more decentralized over the course of the eighteenth century, at least with regard to the way in which colonial revenues were distributed. This feature seems to contradict the conventional notion of the centralising measures undertaken by Bourbon reformer.

${ }^{23}$ For more details see Grafe and Irigoin, "Legacy," Appendix 2. 
Table 3 Average Percentage of Expenditure Going to ICTs for all Cajas

\begin{tabular}{c|c}
\hline & $\begin{array}{c}\text { ICTs as percentage of } \\
\text { expenditure (average) }\end{array}$ \\
\hline 1729 & 54.6 \\
1730 & 56.1 \\
1731 & 53.9 \\
1732 & 59.7 \\
1733 & 51.6 \\
& \\
1785 & 36.5 \\
1786 & 34.4 \\
1787 & 35.2 \\
1788 & 39.5 \\
1789 & 38.4 \\
& \\
1796 & 39.1 \\
1797 & 42.8 \\
1798 & 45.2 \\
1799 & 39.7 \\
1800 & 37.5 \\
\hline
\end{tabular}

Source: See Appendix

By the late $18^{\text {th }}$ century the ICTs themselves had become an important part of the colonial economy everywhere. But even though they constituted essentially payments between two colonial treasury districts, they were not generally affected by the colonial administration. Instead the monies were managed by private merchants who used their own commercial networks to transfer them. This was nothing new given that states everywhere would use private bankers, who used commercial bills to transfer funds form one place to another, though rarely within a country. Yet, the Spanish American system of ICTs was very unusual in that the merchants did not transfer the funds in the form of bills or money but more often than not converted them into merchandise, which was 
then sold at the point of destination. ${ }^{24}$ A typical example of colonial elites as tax-payers and administrators of imperial spending was the administration of alcabalas taxes in Puebla by the local Cabildo (the corporate body of local government) recently studied by Yovana Celaya. Cabildo officials, the oidores, were not only in charge of the collection of revenues. They also participated in the management of royal expenditures for the provision of troops stationed in the Caribbean, the Philippines and Florida in association with local merchants and producers. Oidores paid for some of the foodstuff for the Armada de Barlovento, the Nao de Filipinas and the San Agustin presidio (outpost) with minimal or no intervention of treasury officials. This example of the overlapping between tax payers and tax collectors (or farmers) and tax farmers and royal suppliers in managing the royal monies was the norm rather than the exception in the functioning of the Spanish imperial treasury. ${ }^{25}$

Local control over revenue and expenditure in conjunction with the system of ICTs led to a heavy concentration of royal spending on a few regions. Table 4 below illustrates this in more detail for a number of treasury districts, for which we have population data and can therefore offer per capita estimates. Most cajas had absolutely minimal expenditures on a per capita basis. A second group spent anything

\footnotetext{
${ }^{24}$ See e.g. Eduardo Saguier, "La Conducción De Los Caudales De Oro Y Plata Como Mecanismo De Corrupción. El Caso Del Situado Asignado a Buenos Aires Por Las Cajas Reales De Potosi En El Siglo Xviii," Historia 24 (1989).; Adolfo Meisel, "SubsidyLed Growth in a Fortified Town: Cartagena De Indias and the Situado, 1751-1810," paper presented at LACLIO 2000 (2000).; Johanna von Grafenstein, "Politica De Defensa De La Espana Borbònica En El Gran Caribe Y El Papel Del Virreinato Nuevohispanico," paper presented at LASA conference, Chicago (1998).; Allen J. Kuethe, "Guns, Subsidies and Commercial Privilege. Some Historical Factors in the Emergence of the Cuban National Character 1763-1815," Cuban Studies 16 (1986).; Zacarías Moutoukias, "Power, Corruption, and Commerce: The Making of the Local Administrative Structure in Seventeenth-Century Buenos Aires," in The Atlantic Staple Trade. Volume I: Commerce and Politics, ed. Susan Sokolow, An Expanding World. The European Impact on World History, 1450-1800 (Variorum, 1996).

${ }^{25}$ Celaya Nandez, "La Administracion De Las Alcabalas Poblanas. Ingreso Y Transferencia, 1630-1743" (unpublished PhD, El Colegio de Mexico, 2007).
} 
between three and five pesos per capita. And finally there were the big spenders: In our sample Potosí, Cuzco, Lima, Trujillo, Mexico, Veracruz and Buenos Aires, which topped the list at 32 pesos per capita.

Comparators are hard to come by since wage and income data for Spanish America are notoriously deficient. Yet we have e.g. a good estimate for the per capita spending of a mestizo family in Arequipa (southern Peru), which was about 30 pesos per capita in the late $18^{\text {th }}$ century. ${ }^{26}$ This compares well with Salvucci's estimate for a per capita subsistence income of 34 pesos in considerably richer New Spain. ${ }^{27}$ The price level in Buenos Aires was probably higher than in Arequipa, but it is striking that the Buenos Aires treasury public expenditure per capita was comparable to per capita (mestizo) private consumption in Arequipa. ${ }^{28}$ Per capita public expenditure in the 'big spender' cajas was also notably high when compared with peninsular Spain. Over the course of the $18^{\text {th }}$ century peninsular public expenditure rose rarely above the 2.77 pesos observed in the 1780s, and even in the late 1790s, when the metropolis was in the middle of a war for its own survival it did not rise above 5.5 pesos.

\footnotetext{
${ }^{26}$ K.W Brown, "Price Movements in 18th Century Peru - Arequipa," in Essays on the Price History of 18th Century Latin America, ed. Lyman L. Johnson and Enrique Tandeter (Albuquerque: University of New Mexico Press, 1990), 189-190. A 'Spanish' family in Arequipa spent around 260 pesos a year in 1780 and 240 in 1800, according to Brown and a mestizo family spent 160 and 130 pesos respectively, or about 30 pesos per capita

${ }^{27}$ Richard Salvucci, "Mexican National Income in the Era of Independence, 18001840," in How Latin America Fell Behind: Essay on the Economic Histories of Brazil and Mexico, 1800-1914, ed. Stephen Haber (Stanford: Stanford University Press, 1997), 225.

${ }^{28}$ Mestizos formed the majority of urban population in colonial Spanish America and at the time Arequipa was a mid-sized, well-established market town in an agricultural region in Peru.
} 
Table 4 Net Expenditure and Net ICTs Per Capita 1796-1800: Spanish American Cajas and Peninsular Spain Average (pesos)

\begin{tabular}{|c|c|c|}
\hline & $\begin{array}{r}\text { Net } \\
\text { expenditure } \\
\text { per capita }\end{array}$ & $\begin{array}{r}\text { ICTs per } \\
\text { capita }\end{array}$ \\
\hline La Paz & 3.68 & -5.72 \\
\hline Potosi & 12.86 & 4.75 \\
\hline Mendoza & 2.53 & -0.16 \\
\hline Buenos Aires & 32.15 & 19.85 \\
\hline Catamarca & 0.01 & -0.08 \\
\hline Corrientes & 0.16 & -0.03 \\
\hline Salta & 3.50 & 0.00 \\
\hline San Juan & 0.12 & 0.00 \\
\hline Sta Fe & 1.17 & -0.11 \\
\hline Stgo del Estero & 0.11 & 0.00 \\
\hline Tucuman & 0.16 & -0.05 \\
\hline La Rioja & 0.01 & -0.03 \\
\hline Arequipa & 2.49 & -3.34 \\
\hline Cuzco & 7.48 & -5.17 \\
\hline Huamanga & 4.31 & -5.03 \\
\hline Lima & 10.07 & 6.67 \\
\hline Trujillo & 11.22 & -10.22 \\
\hline Durango & 0.29 & -2.54 \\
\hline Guadalajara & 0.21 & -1.21 \\
\hline Guanajuato & 0.19 & -1.74 \\
\hline Merida & 0.78 & 0.00 \\
\hline Mexico & 21.60 & -2.81 \\
\hline Oaxaca & 0.15 & -0.51 \\
\hline Puebla & 0.92 & -0.09 \\
\hline SLPotosi & 0.24 & -2.68 \\
\hline Veracruz & 29.51 & 2.29 \\
\hline Zacatecas & 4.15 & -4.91 \\
\hline Peninsular Spain average 1785-89 & $\star 2.77$ & \\
\hline Peninsular Spain average 1796-1800 & $\star 5.59$ & \\
\hline
\end{tabular}

* in Spanish American silver pesos (not provinciales)

Source: for Spanish America, see Appendix. For Spain: expenditure from Jurado Sanchez 2006, Appendix II, population from Perez Moreda (1997)

When we compare the expenditure figures with those for ICTs the picture is further complicated. The system clearly produced winners and losers. Some cajas were net payers into the system and some were subsidised through it. But as we have argued before, these patterns were 
not entirely stable over time and in some cajas changed from year to year. Still over the five year period from 1796 to 1800 some patterns are visible. To begin with the picture is slightly misleading because we lack detailed information for many districts that were major recipients of net transfers, especially those in the wider Caribbean, which received large payments from New Spain like Havana and Cartagena. In our sample some of the big per capita spenders, Veracruz, Potosi, Lima and Buenos Aires are the major beneficiaries, (though not Cuzco) while the net payers are more widely distributed over ten districts or so. There is no apparent pattern with regard to the kind of economic structure that existed in these districts. ${ }^{29}$ What does stand out is that commercial centres overall seem to have done very nicely out of the system of transfers.

The system of inter-regional revenue redistribution had by the late $18^{\text {th }}$ century acquired a life of its own. ICTs lubricated trade within the Empire and between colonial regions with a surprising efficiency. The greatest beneficiaries of the system were thus the large trading ports, such as Veracruz, Buenos Aires, Havana and Cartagena de Indias and Montevideo, Lima (Callao) or Valparaiso to a lower degree. Merchants used the transfer of fiscal funds to finance trade between the ports and the hinterland. Thus ICT released liquidity constraints on commercial ventures. Regional elites used the transfers actively as a means to finance inter-regional trade and to enrich themselves in the process. It is well known, that a substantial share, maybe around one quarter to one third of the revenue to be transferred never reached its destination, since merchants and shippers not only used this additional liquidity for their own

\footnotetext{
${ }^{29}$ However, the fiscal contribution from personal tribute paid by indigenous communities in the "net payer" cajas like La Paz, Arequipa, Cuzco, Huamanga, and Trujillo seems to have been relatively larger than elsewhere and proportionally a higher share of the total royal revenues. More research is necessary to provide a definitive assessment. Grafe and Irigoin, "Legacy."
} 
purposes but also charged sizeable transaction costs. ${ }^{30}$ Maybe more importantly, ICTs actually effected a massive redistribution of income, increasing the per capita income especially of ports for overseas trade by a substantial margin. They raised demand in those large agglomerations and are presumably one of the reasons why economic historians have argued that colonial ports like Havana or Buenos Aires experienced very high rates of economic growth in the $18^{\text {th }}$ century. ${ }^{31}$ ICTs thus fulfilled in some senses a function that elsewhere would have been expected to be met by a financial sector: they channelled capital into the fastest growing regions and sectors.

\section{$\underline{\text { IV }}$}

\section{Where did all the Money go? Expenditures by Category}

Large intra-colonial transfers were not the only distinctive feature of the Spanish American fiscal system. A closer analysis of the expenditure categories reveals other important patterns. Table 3 below classifies the expenditure of Spanish American cajas net of all transfers to either Spain or as ICTs by major category of expenditure in columns 2 to 4 . Over the course of the $18^{\text {th }}$ century the amount of civil wage and non-wage expenditure seems to fall at the expense of military expenditure. However, caution is in order since the treasury accounts for the late $18^{\text {th }}$ century contain more expenditure for which the records do not indicate a

\footnotetext{
${ }^{30}$ Irigoin and Grafe, "Bargaining for Absolutism." In De la Sagra's words "the remittances from Mexico never arrive in full" Ramon de la Sagra, Historia Económica, Política Y Estadística De La Isla De Cuba O Sea De Sus Progresos En La Población, La Agricultura, El Comercio Y Las Rentas (Habana: Imprenta de las Viudas de Arazoza y Soler, impresoras del gobierno y capitania general, de la Real Hacienda y de la Real Sociedad Patriotica por S.M., 1831).and Kuethe, "Guns."

${ }^{31} \mathrm{~J}$. Coatsworth, "Economic and Institutional Trajectories in Latin America," in Latin America and the World Economy since 1800, ed. J. Coatsworth and A.M. Taylor (Cambridge/MA: Harvard University Press, 1998).
} 
clear purpose. By the later 1790 s almost 40 percent of expenditure could not be categorised safely.

This is not a problem of source survival; the expenditures in our unspecified category were registered completely normally. But they appear in indistinguishable generic categories such as 'masa del comun', literally 'general mass', which is surprising since overall the treasury accounts for the later eighteenth century are more specific, in that many more disaggregated revenue and expenditure categories appear than earlier in the century. Increasing specificity in recording coincided with the appearance of big, ill-defined lump sums. There seemed to be an increasing number of payments that the treasury officials could not or would not classify clearly within the standard categories employed previously. We will come back to possible explanations later.

Table 5 Expenditure Net of all Transfers by Category, 1729-1800 (\%)

\begin{tabular}{|c|c|c|c|c|c|c|c|c|}
\hline & $\begin{array}{l}\text { Spanish } \\
\text { America }\end{array}$ & $\begin{array}{l}\text { Spanish } \\
\text { America }\end{array}$ & $\begin{array}{l}\text { Spanish } \\
\text { America }\end{array}$ & $\begin{array}{l}\text { Peninsular } \\
\text { Spain }\end{array}$ & $\begin{array}{l}\text { Peninsular } \\
\text { Spain }\end{array}$ & $\begin{array}{l}\text { Britain } \\
\text { peace } \\
\text { time }\end{array}$ & $\begin{array}{l}\text { Britain } \\
\text { war } \\
\text { time }\end{array}$ & France \\
\hline & $\begin{array}{l}\text { 1729-33 } \\
\text { [35 cajas] }\end{array}$ & $\begin{array}{l}1785-89 \\
{[72 \text { cajas] }}\end{array}$ & $\begin{array}{l}\text { 1796-1800 } \\
\text { [72 cajas] }\end{array}$ & $1770 \mathrm{~s}$ & $1780 \mathrm{~s}$ & $\begin{array}{l}\text { Late } \\
18^{\text {th }} \mathrm{C}\end{array}$ & $\begin{array}{l}\text { Late } \\
18^{\text {th }} \mathrm{C}\end{array}$ & 1788 \\
\hline $\begin{array}{l}\text { Military wage } \\
\& \text { non-wage }\end{array}$ & 41 & 28 & 16 & 65 & 60 & 31 & 61 & 26 \\
\hline $\begin{array}{l}\text { Civil wage \& } \\
\text { non-wage }\end{array}$ & 57 & 44 & 38 & 30 & 29 & 13 & 9 & 23 \\
\hline Financial & 2 & 4 & 7 & 5 & 12 & 56 & 30 & 49 \\
\hline Unspecified & 0 & 24 & 39 & & & & & \\
\hline
\end{tabular}

Sources: Spanish America: our estimates, Spain: own elaboration based on Jurado Sanchez (2006). Estimates for Spain by Torres Sánchez (2006) table 1 differs marginally possibly due to rounding and aggregation procedures. Britain: O'Brien (1988), France: Braesch (1936) pp $200 f f$.

Comparing again the Spanish American expenditure with those of peninsular Spain, France and Britain in the late $18^{\text {th }}$ century as yardsticks, a number of points stand out. Just as we saw above that the total size of 
the state was not unusual when compared to the British or French case, the size of the military budget was also well within the same range in Spanish America as in peacetime Britain and France. French spending on wages and non wages for defence (inclusive of Foreign Affairs) represented 26 per cent of the total. ${ }^{32}$ Britain's direct expenditure on military wages and non-wage items was about 30 percent in peacetime and 60 per cent in wartime according to O'Brien; the latter was also the average for peninsular Spain for the later $18^{\text {th }}$ century. Our comparable figures in the Spanish American cajas are 41 percent in the early 1730s, 28 percent in the late 1780 s and 16 percent in the late 1790s. However, most of the 'unclassified' category in the later sample could essentially not be determined because it is not possible to distinguish beyond doubt if it was spent on civil or military wages/items, while we can safely exclude the possibility that it was expenditure involving financial instruments. Hence, if we assume for now that about half of the unclassified items were civil and half military expenditure, the share for direct military expenditure remains in the British and range throughout and lower than the peninsular Spanish one.

The real difference between Spanish American and Spanish expenditure structure on the one hand and that of Britain and France on the other was in the very large Spanish American and peninsular civil expenditure and the tiny financial expenditure. ${ }^{33}$ The latter made up most of the British and French non-military expenditure. As fiscal historians have pointed out it was essentially the result of deferred payments for

\footnotetext{
${ }^{32}$ They amounted to expenses of 165.5 million of lives tournois in the 1788 and included the foreign service according to F Braesch, Finances Et Monnaie Revolutionnaires, Deuxieme Fascicule. Les Recettes Et Les Despenses Du Tresor Pendant L'annee 1799. Le Compterendu Au Raoi, Mars 1788. Le Dernier Budget De L'ancien Regime (Paris: La Maison du Livre Francais, 1936), 200ff. We are very grateful to Joel Felix for sharing this information with us.

${ }^{33}$ See also Rafael Torres Sànchez, "Possibilities and Limits: Testing the Fiscal Military State in the Anglo-Spanish War of 1779-1783," Facultad de Ciencias Economicas y Empresariales Universidad de Navarra, Working Paper 06/06 (2006).
} 
military costs. Between wars Britain and France paid off war debts. Taken together direct military expenditure and time-deferred military expenditure accounted for 90 percent of British expenditure. France allocated a total of 72 percent of total expenditure to military related purposes in the critical year of 1788; 23 per cent went the Civil list and expenses and 49 per cent to debt service, including interest and principal repayments. ${ }^{34}$ In Spanish America interest and debt payments never accounted for more than 7 percent of total expenditure, even less than the 12 percent reached in late $18^{\text {th }}$ century peninsular Spain. ${ }^{35}$ By contrast, civil costs and wages accounted for almost half of the total in Spanish America and a third in the metropolis.

Low interest and debt payments thus mark the difference not only compared to Britain but also to France, which betrays the conventional idea that absolutist fiscal regimes should look broadly similar as a group and be clearly distinguishable from parliamentary ones in such central features as their debt ratios. Colonial treasuries (like their metropolitan counterparts) took relatively few loans before the last decades of the $18^{\text {th }}$ century and even then the total amounts remained small. It should be noted that this was not because Spain engaged in fewer wars than its competitors. From 1700 to 1814 Britain was at war 46 years, France 45 and Spain 51 years. ${ }^{36}$ The high apparent correlation between revenues and expenditure (see table 8 Appendix 1 ) persuaded Klein that "obviously the Crown spent only what it had, and if that income disappeared it did not 'invent' new incomes or go wildly into deficit financing. When income

\footnotetext{
${ }^{34} 145.8$ million livres and 310.4 million for the 1788 fiscal year respectively. See Braesch, Finances Et Monnaie Revolutionnaires, Deuxieme Fascicule. Les Recettes Et Les Despenses Du Tresor Pendant L'annee 1799. Le Compterendu Au Raoi, Mars 1788. Le Dernier Budget De L'ancien Regime..

${ }^{35}$ The low indebtedness of the Spanish peninsular hacienda in the $18^{\text {th }}$ century has recently also been noted by H.V. Bowen and A. Gonzàlez Enciso, Mobilising Resources for War: Britain and Spain at Work During the Early Modern Period (Pamplona: EUNSA, 2006). Introduction.

${ }^{36}$ For France and Britain Mathias and O'Brien, "Taxation," 603, fn601.
} 
declined drastically, so too did expenditures." 37 Torres claimed for the Peninsula that the Spanish Crown was simply opposed to taking up more loans. ${ }^{38}$

But budgetary probity and 'fiscal conservatism' was more apparent than real in the colonies as in the metropolis. To begin with Spanish American colonial institutions had always relied to an extent on traditional Spanish debt instruments such as juros (annual redeemable pensions drawn on earmarked taxes) and censos (especially al quitar, redeemable annuities). Investible capital in Spanish America was traditionally provided by a small number of large investors that were interested in low risk, stable returns over the medium and long term. These included ecclesiastical institutions, the Inquisition, lay brotherhoods (cofradías) and indigenous communities' funds (cajas de comunidades indígenas). The latter were at least on paper investment funds on behalf on the indigenous communities resulting from sales of lands or legal restitutions, 'administered for them' by Spanish and creole officials. In the mideighteenth century these types of institutions accounted according to Alfonso Quiroz for about half of the credit supplied in the Viceroyalty of Peru. ${ }^{39}$ Another significant source of credit was the merchant guilds of the large colonial centres, the consulados. ${ }^{40}$

Though not always visible in the fiscal accounts the Spanish American treasuries used available debt instruments throughout the colonial period. Evidence for such transactions exists for Havana, Mexico,

\footnotetext{
${ }^{37}$ Herbert S. Klein, The American Finances of the Spanish Empire. Royal Income and Expenditures in Colonial Mexico, Peru, and Bolivia, 1680-1809 (Albuquerque: University of New Mexico Press, 1998), 23.

${ }^{38}$ Torres Sànchez, "Possibilities."

${ }^{39}$ Alfonso W. Quiroz, "Reassessing the Role of Credit in Late Colonial Peru: Censos, Escrituras, and Imposiciones," Hispanic American Historical Review 74, no. 2 (1994): 203.

${ }^{40}$ Guillermina Del Valle Pavon, Mercaderes, Comercio Y Consulados De Nueva España En El Siglo Xviii (Mexico: Instituto Mora, 2003).
} 
Lima, New Granada, Santiago de Chile and Guatemala. ${ }^{41}$ Much of the financing need was initially driven by the volatility of expenditure. Military investments and other large-scale outlays were never perceived as 'annual' expenditures. It is obvious from the accounts that the expenditure side was never governed by annual regularity, a feature also noted by Klein. ${ }^{42}$ Short-term credit had to be raised against future income. More importantly debts were written into a multitude of private contracts of apparent military and civil nature; presumably one reason why hard-todefine general categories began making up a large chunk of total expenditure as shown in table 5 . Merchants supplied the state, regularly advancing large amounts of funds to provision militias or fulfil administrative functions. Officials were private entrepreneurs that covered the outlays of such essential government functions as tax collection or adjudication against presumed future repayments.

As the financing needs of the Spanish American cajas increased the state impacted more on local credit markets. The situation was aggravated by the expulsion of the Jesuits in 1767, which resulted in a one-off windfall from expropriated property but also dried up an important source of colonial credit. ${ }^{43}$ The colonial treasuries had also abused the state administered Indian trust funds on such a scale that they were depleted and unwilling to continue lending. Towards the second half of the eighteenth century other traditional lenders in several of the large markets became more apprehensive about lending to the colonial hacienda after the Crown lowered unilaterally the interest rates paid on

\footnotetext{
${ }^{41}$ de la Sagra, Historia Económica.; Quiroz, "Credit."; Marichal, La Bancarrota, 97 fn92. Timothy E. Anna, The Fall of the Royal Government in Mexico City (Lincoln: University of Nebraska Press, 1978).; Johanna von Grafenstein, "Mexico Y El Caribe Durante Los Anos De La Emacipacion" (Universidad Autonoma de Mexico, 1994).

${ }^{42}$ Klein, The American Finances, 7-8.b

${ }^{43}$ Confiscated Jesuit assets, mainly rural estates and censo funds, were sold to private bidders. "Property was sold at $80 \%$ of their value at terms ranging from 3 to 50 years. Total revenue for the Treasury amounted to 4.5 million pesos, of which one third consisted of censos and capellanias" Quiroz, "Reassessing the role of Credit" p 219-20
} 
loans. Credit rationing ensued but was countered in much the same way as in the Peninsular. Small investors were reassured through the bundling of loans under the control of the influential consulados.

Effectively these guilds performed as merchant banks. ${ }^{44}$ As agent for a 'syndicate' they were able to place large loans in the market by breaking them into smaller amounts, not unlike an investment bank. ${ }^{45}$ The Consulado could negotiate more efficiently with the colonial state and thus guarantee the servicing of the public debt from the point of view of the small creditors. At the same time it acted as fiscal and financial agent of the Crown but their service was not free of charge for the colonial Treasury. The Consulados of Lima and Mexico received the privilege of collecting the main taxes on trade, international and domestic, since their establishment in the late $16^{\text {th }}$ century. Both received monies from the public (members, other individual merchants and religious institutions) on behalf of the Treasury, the Real Hacienda, against the guarantee of the yield of such taxes. ${ }^{46}$ Until 1754 in Mexico and 1777 in Lima, the Consulado was entitled to the collection of alcabalas (domestic excise) and averías (overseas trade tax), which then passed under the control of Treasury officials. ${ }^{47}$ But this proved temporary. The Consulados regained the collection of averias and with the increasing demand for funds from

\footnotetext{
${ }^{44}$ See Appendix 2 for examples.

45 "As far back as 1627 the Consulado of Lima had raised loans among local creditors at interest rates as high as 17 per cent in order to provide emprestitos and donativos at no additional interest" Quiroz, "Credit," 224,229. See also Guillermina Del Valle Pavon, "El Apoyo Financiero Del Consulado De Comerciantes a Las Guerras Españolas Del Siglo Xviii," in El Crédito En Nueva España, ed. M Martinez Lopez-Cano and Guillermina Del Valle Pavon (Mexico: Instituto Mora, 1998).

${ }^{46}$ These were fixed term concessions for a number of years to collect the tax, (asientos or encabezamiento), which were periodically re-negotiated between the corporation and the highest royal authorities in the colony. For Peru Robert Sidney Smith, El Indice Del Archive Del Tribual Del Consulado De Lima (Lima: Archivo Historico del Ministerio de Hacienda, 1948). Introduction and our Appendices 3 \& 4 for examples.

${ }^{47}$ The Mexico Consulado also financed the coinage of silver in the Mexico City mint house. Guillermina Del Valle Pavon, "Los Excedentes Del Ramo De Alcabalas, Habilitacion De La Mineria Y Defensa Del Monopolio De Los Mercaderes De Mexico En El Siglo Xviii

" Historia Mexicana LXI, no. 3 (2007).
} 
the war with France after 1780, the alcabala too fell back in the hands of Consulados. In smaller port towns and markets these levies continued to be farmed to individuals or local corporations. With each additional donativo or loan requested by the Crown or its representatives in the colonies Consulados obtained a rise in the tax or additional levies which became collaterals for the subscription of capital among the public. At the same time monies were increasingly lent at interest to the crown, and lenders whose funds were syndicated through the Consulado preferred to maintain their capital in the hands of the corporation for longer periods if at a lower interest in return. The Consulado in Lima, e.g., was paid by first retaining and then expanding the averia and later received a new 1.5 percent tax on silver exports in return for syndicating a 1.5 million pesos loan to fund the war against the Portuguese in the River Plate. ${ }^{48}$

Non-monetary payments for services were always a large part of the equation and explain another share of public debt that never showed in the accounts. As early as the 1670s the merchant guild of Lima agreed to give some emergency loans for the defence of the Viceroyalty "ostensibly [...] as a means of avoiding an increase in fixed taxation." ${ }^{49}$ In parallel with developments in peninsular Spain, the state's financing needs were often not covered by specific financial market transactions but by co-optation of individuals and a large number of contracts, which today in Britain would be euphemistically called 'public private partnership' ${ }^{50}$

"The best way for merchants in Peru to assure royal support for their demands and counteract peninsular competitors was to provide loans to the Royal Treasury and guarantee their

\footnotetext{
${ }^{48}$ Loans with similar or larger guarantees repeated in the 1780s when the Crown granted the collection of the additional tax on bullion exports from other ports elsewhere in South America. See Appendix 3 and 4

${ }^{49}$ Quiroz, "Credit," 210.

${ }^{50}$ Bowen and Gonzàlez Enciso, Resources.
} 
payment. In this way the Consulado of Lima was behaving much like the Cádiz merchants, the Cinco Gremios Mayores de Madrid, and the companies of Caracas and La Habana." ${ }^{51}$

The privatisation of state functions thus guaranteed the availability of credit for the regional Spanish American cajas. The enmeshing of private interests and public accounts was of course the very nature of ancient regime rule but the differences between French financing patterns and Spanish ones illustrate that they could play out in very distinct ways .

Still, there is no reason to assume that this represented some "archaic" or old form of financial instruments. ${ }^{52}$ Citing so-called donativos 'donations' and 'interest free' loans to the colonial treasuries Marichal argued that these were based on coercion and/or implied social obligations of the elites. ${ }^{53}$ By contrast, Baskes considers them "virtually bribes" paid to the Crown in exchange for rulings in the lenders favour. ${ }^{54}$ Donativos had formed part of the peninsular and colonial tax structure

\footnotetext{
${ }^{51}$ Quiroz, "Credit," p.217.

${ }^{52}$ The persistent notion that credit markets in Spain and Spanish America were underdeveloped because of religious controls over usury is clearly contradicted by more recent research. From the $16^{\text {th }}$ century onwards usury laws were circumvented by drawing up juros and censos in such a way that they represented a contract, where the lender (censualista) essentially acted as a buyer of 'proceeds' (reditos) sold by the debtor (censatorio). This rephrasing converted a potentially usurious credit transaction into a perfectly legitimate sale of a good (the proceeds from the loan) as long as the interest rate stayed within the going market price for such a sale (precio justo), i.e. what we would think about as the market interest rate. Jose Antonio Alvarez Vazquez, Rentas, Precios Y Credito En Zamora En El Antiguo Regimen (Zamora: Colegio Universitario de Zamora, 1987), 256ff. This explains why credit instruments were sold and bought without restrictions, why religious institutions acted as the largest credit intermediaries without any qualms and why secondary markets in financial instruments were readily available all over Spain and Spanish America. For Spanish America, see Quiroz, La Deuda Olvidada,

${ }^{53}$ Marichal, La Bancarrota, p.99. The English version of the book offers a more nuanced version of the argument. Marichal, Bankruptcy, 84-87.

${ }^{54} \mathrm{~J}$ Baskes, "Risky Ventures: Reconsidering Mexico's Colonial Trade System," Colonial Latin American Review 14, no. 1 (2005): 34. In 1821, the Lima Consulado sent a representative to Madrid asking for bold military actions against the rebels who were at the doors of Lima and reminded the (restored) King Ferdinand VII in great detail of 7.3 million pesos total that the merchants' guild had lent or "donated" to the Treasury since 1806. A Real de Asua, "Representacion Hecha Por El Consulado De Lima a S.M.," Madrid M Reppulles (1821).
} 
since the sixteenth century and are more correctly described as a mixture of extraordinary taxes and loans. A closer look at the conditions and interest payments included in the so-called forced loans and donations to the colonial treasury illustrates that these were complex contracts but clearly not a free lunch for the treasuries.

Table 9 in the Appendix 1 provides a list of loans the Mexican treasury took out in the late $18^{\text {th }}$ century according to Marichal's very complete analysis and Table 10 offers similar information for Peru. Given that this was a period of warfare and conflict the pressure on the colonial treasuries was higher than ever. By 1816 the Mexican treasury was indebted to Mexican institutions and individuals to the tune of 80 million pesos roughly equivalent to 120 percent of its 1796-1800 annual revenue. ${ }^{55}$ Some loans stipulated a regular interest rate and most devised additional benefits for the creditor and - more importantly - clearly defined collateral in the form of a specific tax that would be earmarked for repayment. Even when the interest rate charged was not explicit in the contracts and when their complicated form makes it hard for historians to price them it is fairly obvious that they did carry a cost for the Treasury cajas. Contracts between the regional treasuries and individuals often included future tax breaks, surcharges, arbitrage gains by using silver coins of different qualities, complicated types of collateral and contractual penalties and royal privileges and offices. To interpret even such items as titles of nobility granted against "services" rendered to the Crown as a sign of some form of "social obligation" towards the Crown in an almost medieval way completely misses the point that relations between Crown and subject were based on mutual rights and duties that had a price tag to them. Noble titles involved tax advantages and rights to the creation of entails. They also were valuable 'brand names' that allowed the owner access to lines of credit, business contacts and lucrative marriage

${ }^{55}$ Klein, The American Finances, 89. 
options. ${ }^{56}$ More research needs to be done on the actual contracts to estimate the implied interest rates charged. But for now it stands to reason that the system was not necessarily unusually corrupt, though it lacked transparency. But it is not obvious that it was actually either an expensive nor particularly expropriatory way of running an Empire.

In many ways the Spanish Empire was quite adapt at using market competition to its own advantage. The history of the 'forced loans', so common in many early modern fiscal systems, has yet to be written. Premodern factor markets were served by contractual arrangements that often included a mixture of 'force' and 'choice'. Just as labour markets were governed at the same time by free labour contracts, left-over's of traditional pre-Columbian labour relations, apprenticeships, indentures, slavery with manumission and slavery without any chance to attain freedom, credit contracts could exhibit the full range from force to choice. ${ }^{57}$ On such a scale the Spanish and Spanish American 'forced loans' were subject to a relatively weak form or exertion of sovereign power. In practice they amounted often to little more than a syndicated loan that produced a decent fee for the agent and was subscribed voluntarily by individual investors. Compare this to Florentine forced loans of the $15^{\text {th }}$ century or forced loans in the Province of Holland into the early $17^{\text {th }}$ century, which distributed the principal on the basis of lists of wealth of citizens forcing every single individual to take a portion of the loan according to what the state (not the investor) decided he or she could bear. Though beyond the topic of this paper it is possible that there was less pressure for an abolition of forced loans in the Spanish context than

\footnotetext{
${ }^{56}$ R Rizo Patron Boylan, Linaje, Dote Y Poder. La Nobleza En Lima De 1700 a 1850 (Lima: PUCP, 2000), chapter 1. D.M. Ladd, The Mexican Nobility at Independence (Austin: University of Texas Press, 1976).

${ }^{57}$ For Colonial Spanish America labour see J Monteiro, "Labor Systems," in The Cambridge Economic History of Latin America, ed. Victor Bulmer-Thomas, John H. Coatsworth, and Roberto Cortes-Conde (Cambridge: Cambridge University Press, 2006). Ch 6
} 
in some other places, notably Holland, because the particular contractual arrangement practiced by the Spanish treasuries was certainly by the $18^{\text {th }}$ century seen as a business opportunities by corporate interests and wealthy individuals who invested in them rather than a very real threat to the economic viability of even very well to do merchants as in $15^{\text {th }}$ century Florence or a widely shared burden like in Holland in the early $17^{\text {th }}$ century. ${ }^{58}$

Another example of use of market forces was the sale of offices no matter how offensive to modern ideas of independent state bureaucracies. Historians have long condemned the sale of office as a mechanism that was born out of extreme fiscal needs, and through which unscrupulous and incompetent men took the government in their hands contributing to the decline of Imperial Spain. ${ }^{59}$ That abstracts from the fact that the purchase of offices, and hereditary and transferable posts, existed since very early times as means to man the government of the colonies ${ }^{60}$ Sales continued in the $17^{\text {th }}$ century and under the new dynasty in the $18^{\text {th }}$ century. During the Habsburg period a large variety of minor appointments, municipal, notarial and 'miscellaneous fee earning' positions went on sale. ${ }^{61}$ From the early $17^{\text {th }}$ century onwards, with the expansion of the empire the extension of the bureaucracy opened

\footnotetext{
${ }^{58}$ For Florence see Lauro Martines, "Political and Social Strains In "Quatrrocento" Florence," The Journal of Modern History 60, no. 2 (1988). for the Netherlands Oscar Gelderblom and Joost Jonker, "Collective Spirit or Aggregate Wealth? Understanding the Structure and Growth of Holland's Public Debt, 1514-1713," paper presented at Rutgers Workshop in Money, History and Finance (2008).

${ }^{59}$ The classical source for the sale of bureaucratic offices as one manifestation of the Spanish decline in the 17th century is J. H. Parry, The Sale of Public Office in the Spanish Indies under the Hapsburgs (Berkeley: University of California Press, 1953). ${ }^{60}$ The crown used the power of patronage to compensate for services with a grant of offices by means of a merced since early $16^{\text {th }}$ century. Mark A Burkholder and D.S. Chandler, "Creole Appointment and the Sale of Audiencia Positions in the Spanish Empire under the Early Bourbon, 1701-1750," Journal of Latin American Studies 4, no. 2 (1972). Mark A Burkholder and D.S. Chandler, From Impotence to Authority. The Spanish Crown and the American Audiencias, 1687-1808 (Columbia, MO: 1977), 26. ${ }^{61}$ These posts were usually hereditary and transferable sold through public auction Burkholder and Chandler, "Creole Appointment," p.188.
} 
positions for sale including the highest posts in the judiciary (Audiencia), the treasury and the tribunal de cuentas, the supervisory body of all treasuries, tax farmers and final Court of Appeal in tax matters. ${ }^{62}$

There is plenty of evidence that there was a reasonably competitive market for offices that reflected location and capacity of the post. The top prizes were Viceregal positions, which were occasionally sold. Beyond those the post of contador mayor (chief treasurer) in Lima fetched the 20,000 pesos in the $18^{\text {th }}$ century, while a post in the Audiencia could be had for $12,000 .{ }^{63}$ When no vacancies were available the crown sold repeatedly futuros - the promise of appointment to a future vacant office. Posts were acquired through individual private transactions, though the purchaser had to fulfil general requirements of competence for treasury posts and the Crown guarded against corruption through requiring high security bonds (collaterals), which in Lima could reach between 20,000 and 45,000 pesos. Given the high cost of these collaterals some of the bids for high office in Lima involved a syndicate of merchants and financiers who gathered the amount in advance for the bond. This mechanism of filling colonial administration was a far cry from a professionalised bureaucracy, but it responded to economic incentives. As Root has pointed out, in pre-modern states the choice was generally one between corruption and nepotism; and the former had the distinct advantage of handing the prize to the individual with the largest economic

\footnotetext{
${ }^{62}$ Kenneth J. Andrien, "The Sale of Fiscal Offices and the Decline of Royal Authority in the Viceroyalty of Peru," Hispanic American Historical Review 62, no. 1 (1982): p.55. ${ }^{63}$ Juvenal Luque, "La Data De Los Salarios De La Caja Real De Lima, Siglo Xvii-Xviii," in Congreso de Historia Economica (Lima PUCP: 2008). Andrien, "The Sale," p.57. and MA Burkholder and DS Chandler, "Creole Appointments and the Sale of Audiencia Positions in the Spanish Empire under the Early Bourbons, 1701-1750," Journal of Latin American Studies 4, no. 2 (1972), Burkholder and Chandler, "Creole Appointment," p.204. For the sale of office of viceroy in Peru and New Spain in the 1690s see A Dominguéz Ortiz, "Un Virreynato En Venta," Mercurio Peruano 49 (1965): 46-51.
} 
interest in obtaining it, in other words it at least maximised marginal return. ${ }^{64}$

But the pricing structure for these offices also reveals that the sales did not only reflect the potential returns of corruption. In the $18^{\text {th }}$ century creoles faced barriers to entry as holders of governmental office. ${ }^{65}$ They were never excluded from office holding, but more creoles than peninsulares (those born in Spain) had to purchase their offices rather than receiving them as a merced (grant). ${ }^{66}$ Those creoles, who finally held positions in the Audiencias, regularly paid considerably more for their positions than the peninsulares, who became American office holders. ${ }^{67}$ Generally, this has been interpreted as a sign of discrimination against creoles and an attempt by the Crown to limit local influence even if its success was limited. ${ }^{68}$ If differential pricing reflected the Crown's desire to make sure that the creoles did not become too powerful, it also reveals another obvious truth: the purchase of offices was potentially more lucrative for members of the elites with strong local, American connections. This was precisely why they were willing to pay a higher

\footnotetext{
${ }^{64}$ Hilton L Root, "The Redistributive Role of Government: Economic Regulation in Old Regime France and England," Comparative Studies in Society and History 33 (1991). Root's point was that the English Parliament was corrupt, while the French administration was governed by nepotism. Interestingly, France as opposed to Spain, never sold offices in its colonies leaving less room for local representation.

${ }^{65}$ This has been a persistent claim, starting with Simon Bolivar among others, in the wake of Independence, see his 'Jamaica letter' of 1815. Historians have confirmed this, see e.g. John Leddy Phelan, The People and the King: The Comunero Revolution in Colombia, 1781 (Madison: University of Wisconsin Press, 1978), p.9. and John Leddy Phelan, The Kingdom of Quito in the Seventeenth Century: Bureaucratic Politics in the Spanish Empire (Madison: 1967), p.145. However, Phelan also noted the creole dominance in the Audiencia of Bogota and David Brading identified the same distribution in the composition of the Audiencia of Mexico in the $18^{\text {th }}$ century. D.A. Brading, Miners and Merchants in Boubon Mexico, 1763-1810 (Cambridge: 1971). ${ }^{66}$ Burkholder and Chandler, "Creole Appointment," p.191-192.

${ }^{67}$ Phelan, The People and the King : The Comunero Revolution in Colombia, 1781, p.9.

68 "Most of those who purchased (fiscal) offices were already resident in the Indies" and "(this) led to a significant increase in the number of local personnel recruited to serve the crown". "By the end of the century the crown routinely approved sales to native sons of Lima" Andrien, "The Sale," pp.59-60.
} 
price for the same office compared to a prospective peninsular officeholder. ${ }^{69}$

Locally born office holders had the same powers to extract backhanders as peninsulares, so there is no reason why locals should have been willing to pay more for the office on the grounds of potential returns to corruption. But being well connected in the local business community seems to have mattered in order to realise the maximum benefit from office-holding. Here is another indicator how closely royal officials' and local elites' economic activities were integrated. Differential pricing for American offices between creoles and peninsulares might just have reflected the market value of the office for either group. Consequentially, wealthy neighbours were usually the ones to provide the bonds required for treasury offices 'socialising' the returns from officeholding by a fellow creole. ${ }^{70}$

The very expansion of the colonial administration from about 35 treasury districts in the 1730 s to over 70 (table 2 and 6 ) in the late $18^{\text {th }}$ century was a result of the extension of the colonial state towards its boundaries in the Southern Cone and the northern Mexican regions as well as less developed interior regions. All of this development was, like the entire Spanish colonial enterprise, self financed. Existing colonial districts acted as springboard. In relay fashion, they organised and financed the successive establishment of new immigrants from Spain and of the state in new regions. Thus, if aggrandisement of the Empire was the maximisation target of the Spanish Crown it was remarkably successful at almost no direct cost to itself.

\footnotetext{
${ }^{69}$ This is corroborated by Ibid.: p.62. "Creoles and even native sons were apparently willing to outbid peninsular claimants for the posts. Apparently the high prices they were willing to pay also led officials in Madrid to ignore any legal obstacle to their holding office".

${ }^{70}$ Ibid.: pp.64-65 and 69-70. gives examples of such bonds.
} 
Table 6 Expenditure of Spanish American cajas net of all transfers by category

\begin{tabular}{|l|c|c|c|}
\hline Expenditure category & $\begin{array}{l}\text { \% of total } \\
\text { expenditure } \\
1729-33 \\
(35 \text { cajas })\end{array}$ & $\begin{array}{l}\text { \% of total } \\
\text { expenditure } \\
1785-89 \\
\text { (72 cajas) }\end{array}$ & $\begin{array}{l}\text { \% of total } \\
\text { expenditure } \\
1796-800 \\
\text { (72 cajas) }\end{array}$ \\
\hline Direct mining subsidies & 12 & 10 & 15 \\
\hline Direct tobacco subsidies & - & 5 & 4 \\
\hline $\begin{array}{l}\text { Wages (military/civil/church) excl tax } \\
\text { collection cost }\end{array}$ & 12 & 21 & 17.3 \\
\hline Goods and services & 68 & 24 & 10 \\
\hline Welfare and public works & 0.6 & 4 & 1.9 \\
\hline Collection costs (fees and taxes) & 5.8 & 9 & 6.3 \\
\hline Unspecified & 0 & 24 & 29.2 \\
\hline
\end{tabular}

Source: Appendix 1

But there was an indirect cost. The Crown in return not only allowed almost all of its revenue to remain in the colonies but it also coopted colonial elites by letting them manage revenue spending. The outcome was not surprisingly that much of the revenue was fed back into the local economy right away. Table 6 offers a more detailed break down of expenditures of Spanish American cajas net of all transfers. Tax collection costs were actually not very high, between 6 and 9 percent. Neither was this state paying a lot for welfare provision (still largely the domain of the Church) or public infrastructures (often in the hands of towns or merchants' and miners' corporations which in turn might subcontract). Instead it directly subsidised some of the most important sectors of the economy, mining and tobacco production. ${ }^{71}$ Rather than extracting revenue from the mining sector, as has often been alleged, the main sources of revenues were taxes on trade and consumption. Thus,

\footnotetext{
${ }^{71}$ As shown in Rafael Dobado, "El Monopolio Estatal Del Mercurio En Nueva Espana Durante El Siglo Dieciocho," Hispanic American Historical Review 82, no. 4 (2002).
} 
the Spanish colonial state acted more like a developmentalist state that subsidised the development of the export sector, namely in mining and tobacco. And the rest of its expenditure went indirectly back into the local economy in the form of wages and locally purchased goods and services.

\section{$\underline{\mathbf{v}}$}

\section{Where the Money did not go}

Historians have always noted that the Spanish Empire seemed to be spending rather little on the enforcement of its rule. ${ }^{72}$ For the Crown or the colonial elites it was not easy to establish a systematic recourse to repression without an equivalent investment into some means of enforcement; a price the Crown was not willing or able to pay as Coatsworth has recently pointed out and the low spending on colonial bureaucracies and standing armies we can glance from the fiscal accounts confirm. ${ }^{73}$

This was also the view of traditional military historians of the Spanish Empire, who considered that the colonial military establishment before the Seven Years wars "was hardly more than token". ${ }^{74}$ Table 7 summarises the available information. Before the 1760s there were few regular troops. After the 1760 s the intensification of British, French and Portuguese threats to the Spanish possessions led to an enlargement of the regular army and navy. But most troops were stationed in the circum-

\footnotetext{
${ }^{72}$ Noting that initial forced indigenous labour schemes evolved into all sort of informal and temporary arrangements over time Lockhart \& Schwartz pointed at the "weakness of the institutional means of enforcement" and "the little policed countryside". An unsurprising fact "considering how relatively weak and inactive government in the Indies was" Lockhart and Schwartz, Early Latin America, 140, 142 and 148-149. emphasis added.

73 Coatsworth, "Political Economy."

${ }^{74}$ Lyle N. McAlister, "The Reorganization of the Army of New Spain, 1763-1766," Hispanic American Historical Review 33, no. 1 (1953). 2 For the increase in military spending see also Leon G Campbell, "The Army of Peru and the Túpac Amaru Revolt, 1780-1783," Hispanic American Historical Review 56, no. 1 (1976): p.35.
} 
Caribbean region or other strategic areas on the route to the Cape Horn.

The viceroyalty of New Spain with 5.8 million inhabitants had about 6000 regular troops, of whom most were located far away from the densely populated areas. ${ }^{75}$

Table 7 Size of Regular Army in Spanish America

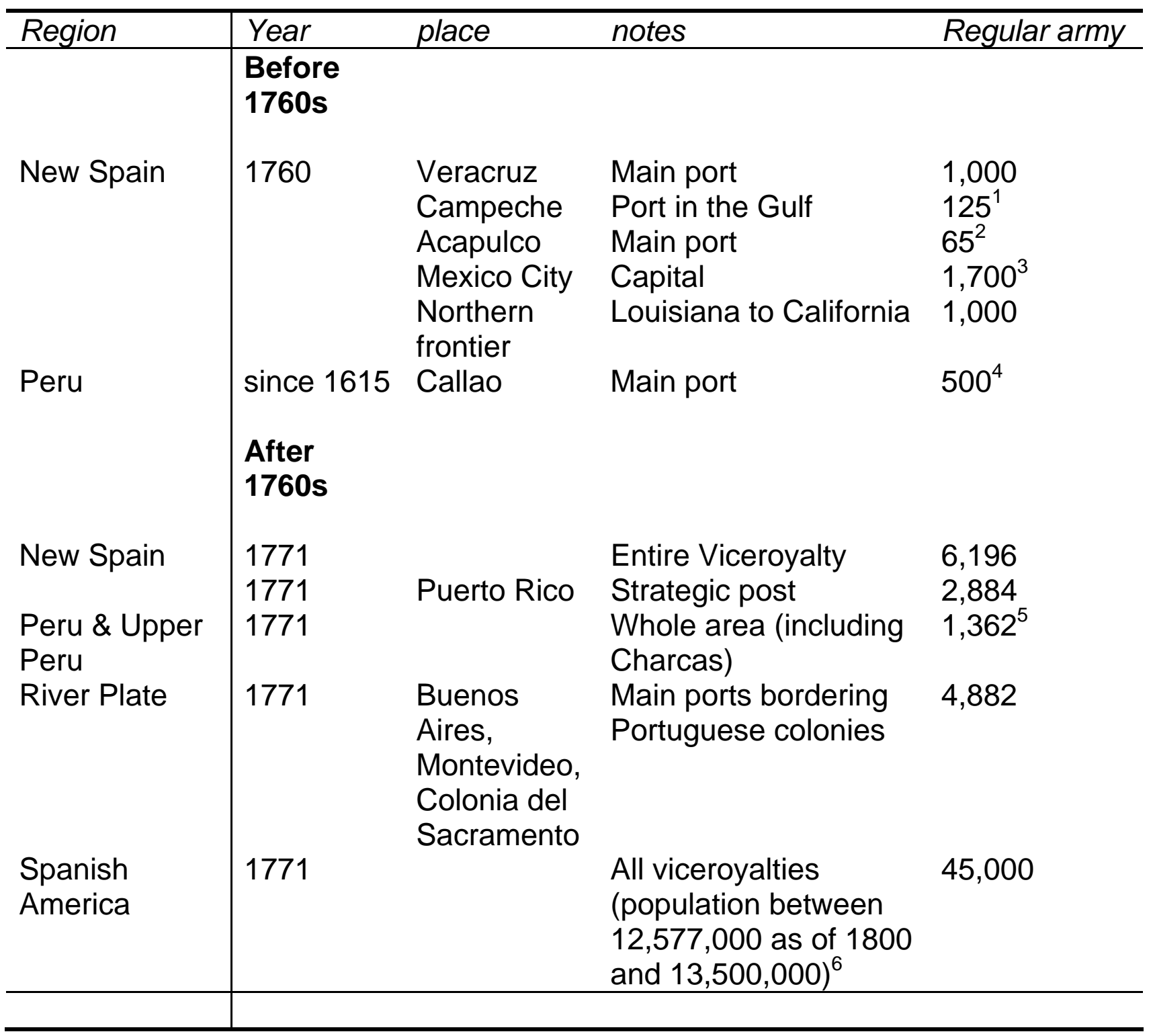

Source: New Spain, Veracruz, Campeche, northern frontier McAlister (1953); Peru and Upper Peru Campbell (1976); River Plate McAlister (1953) fn65, 33.

\footnotetext{
${ }^{75}$ New Spain's population amounted to 5,837,000, exclusive of Central America which totaled 1,160,000. The Spanish Caribbean had 550,000 inhabitants. Lockhart and Schwartz, Early Latin America, 338.
} 
1) 125 men from a detachment of infantry, artillery and dragoons.

2) 52 infantrymen and 13 artillerymen.

3) Includes cavalry and infantry, whose main duties were to guard the viceroy and his palace, the treasury, prisons and other public buildings. This contingent also performed as law enforcing body in aiding civil magistrates.

4) Troops serving for most of the $17^{\text {th }}$ century enlisted always less than the 500 men assigned. This total contingent also manned the presidios in Chile and the royal navy anchored at Callao. Lima had apparently never more than 275 men in the city. Campbell (1976) p.33. Peru was never militarized before the massive rebellions of mainly indigenous peasants around 1780 .

5) Frequent attacks by the Dutch in the late 1680s and 1690s, or even the incursions of Morgan on the Pacific coast of Panama did not alter the size of the Spanish regular detail.

6) Population for 1800 from Lockhart \& Schwartz, Early Latin America, 338. and Sanchez Albornoz (1984) 34.

In fact, Peru and other colonies in South America had long relied on battalions of local militiamen who were mobilized during times of emergency, such as the attack of a small Dutch fleet (sponsored by the VOC) on Callao (Lima's port) and Guayaquil or the constant threat of pirates to Panama in late $16^{\text {th }}$ and the $17^{\text {th }}$ centuries. ${ }^{76}$ Increasingly, the expense for the recruiting and fitting out of the local militiamen moved from the direct responsibility of royal officials in Lima to the purses of municipal corporations, local merchant guilds and landowners. ${ }^{77}$ The colonial militia organized as small military units, received periodic training and were mobilized to reinforce or replace regular units. They were regarded as law enforcers and existed throughout the empire, in cities and rural areas, in proportion to the size of local population (roughly 1 man for every 25 families). Soon they outnumbered the size of regular armies, as in New Spain where in 1766 about 13,000 rural and urban

\footnotetext{
${ }^{76}$ Juan Marchena, "La Financiación Militar En Indias. Introducción a Su Estudio," Anuario de Estudios Americanos 36 (1979).

${ }^{77}$ For an example in $17^{\text {th }}$ Century Peru see L.A Clayton, "Local Initiative and Finance in Defense of the Viceroyalty of Peru: The Development of Self-Reliance," Hispanic American Historical Review 54, no. 2 (1974).
} 
militiamen reinforced the strength of the 2,341-strong regular army, including cavalry, artillery and infantry. ${ }^{78}$

This limited military might - hardly significant for a region inhabited by some 5 million people - was essentially a paper army. Charles III repeatedly instructed his envoys and military officials to exert the outmost care in their relations with local populations when classifying and enlisting recruits for the militias. Colonials were apparently very reluctant to join the military apparatus of the empire and even these modest forces could only be levied by granting extensive privileges and exemptions. ${ }^{79}$ The Spanish Caribbean (Hispaniola, Puerto Rico and Cuba) after the losses of Jamaica, and (temporarily) of Havana and Manila, was the colonial region with the strongest military presence of the Empire. Allen Kuethe has shown how the Crown's special envoys in the later $18^{\text {th }}$ century had to concede far reaching commercial privileges to the powerful planters and merchants of Cuba for their support in establishing a militia of 7,500 men: they were allowed to trade freely with Neutrals, i.e. North American merchants, and intermediate the bulk of Mexican silver that royal and private remittances tended to concentrate on its shores. ${ }^{80}$

Rather than behave like a revenue-hungry empire, Spain chose to buy off regional elites in America to defend strategic interests. This empire run on the cheap left it to the often desperate and ill-prepared local militias to fend off continuous attacks of pirates and other European navies. "So disorganized and unarmed was the local militia" that in 1740 when British Admiral Anson was about to capture the port city of Paita

\footnotetext{
78 "Estado que manifiesta el en que se hallan las tropas de que se compone el Ejercito de Nueva Espana" August 23, 1766 cited in McAlister, "The Reorganization."

${ }^{79}$ The best know privilege was the Fuero Militar for life, the enjoyment of military jurisdiction in all legal affairs, civil and criminal. But officers were also exempted from taxes and exactions and the provincial (rural) militias were exempted from paying the tribute. Militiamen were entitled to pensions and gratuities.

${ }^{80}$ Allen J. Kuethe, "The Development of the Cuban Military as a Socio-Political Elite, 1763-1783," Hispanic American Historical Review 62, no. 4 (1981). shows how trading privileges of all kinds bolstered the sugar economy, which boomed in subsequent years.
} 
north of Lima and the town ran out of shot, "it resorted to loading their cannon with (silver) pesos fuertes in a ludicrous effort to save the city" 81

Where external defence relied largely on local militias, any internal repression required the co-optation of, and more often the initiative from, local colonial elites. ${ }^{82}$ Small contingents of Spanish regular troops could hardly enforce any policy against determined colonial resistance, which consequentially had to be avoided and if necessary negotiated away. In that the empire was apparently quite astute. Tax collection costs were rather modest (see table 6), suggesting that the legitimacy of taxation system overall was not systematically challenged by the population. There were several large tax rebellions, but these were usually precisely reactions to eager reformers, who attempted to alter the status quo negotiated in particular regions. Eighteenth century reformers found out more than once that these 'novelties' were fiercely resisted by unlikely alliances that could stretch the social divisions of colonial society and reformers generally had to give in precisely because no serious repressive apparatus was available. ${ }^{83}$

It is extremely difficult to find out how much repression the state paid for, not just in Spain and her colonies but in almost all early modern states, of which few maintained a regular policing force. France is one of these exceptions. England on the other hand relied largely on the 'voluntary' service of justices of peace, magistrates and constables,

\footnotetext{
${ }^{81}$ Vargas Ugarte, Historia del Peru, pp 189-193 cited in Campbell, "The Army," p.35, fn12.

${ }^{82}$ Brian Hamnett, like many other historians, assigns the nature of Spanish rule to the pervasiveness of corruption "since royal bureaucracies could neither be neither adequately staffed nor adequately paid, inefficiency and corruption, collusion and extemporary practices filled this vacuum, where perhaps representative institutions might have stood". B Hamnett, "Process and Pattern: A Re-Examination of the IberoAmerican Independence Movements, 1808-1826," Journal of Latin American Studies 29, no. 1 (1977). 292.

${ }^{83}$ For more details see Irigoin and Grafe, "Bargaining for Absolutism." and Irigoin and Grafe, "Response.".
} 
although their reputation for corruption was such that there presumably was a substantial pecuniary incentive at least in the larger towns. ${ }^{84}$

How was Spanish rule in the colonies enforced in the absence of any serious repressive machinery? We have to speculate and what follows is largely conjecture. Probably jurisdictional fragmentation so ingrained in Spanish colonial rule again offers part of the answer. Just as different groups in colonial society were subject to different rates of taxation so they were subject to different jurisdictions. Fueros governed substantial parts of colonial population. These were traditional peninsular 'freedoms', i.e. special privileges, which in Spain could apply either to territories or particular groups. Practically every Spanish town and historic territory had its own fueros, but so did the clergy, the military orders, the nobility or certain corporations such as guilds and consulados. The latter group specific 'freedoms' were generally transferred directly to Spanish America and became a part of the legal organisation of the republica de los Españoles, i.e. the Spanish population in the colonies. But the system was adapted in that largely separate legal rules were accepted to govern the republica de los Indios, the American indigenous population. In addition, indigenous communities were allowed to use traditional means and institutions of conflict solving. ${ }^{85}$

Whereas the local militias performed the role of enforcers of the magistrates' decisions, the main institution in matters of criminal justice, the Tribunal of the Acordada, operated in a similar fashion. In New Spain, the Tribunal imposed and executed criminal sentences while placing the centralized police authority in the hands of the viceroy (and hence the militias and the law enforcement arm). The majority of its agents served

\footnotetext{
${ }^{84}$ Clive Emsley, Policing and Its Context, 1750-1870, 1st American ed. (New York: Schocken Books, 1984).

${ }^{85}$ See e.g. Woodrow Borah, Justice by Insurance. The General Indian Court of Colonial Mexico and the Legal Aides of the Half-Real (Berkeley, Los Angeles and London: 1983), Lockhart and Schwartz, Early Latin America.
} 
without compensation, so local landowners and merchants populated its cadres. Having a stake in controlling crimes against property the tribunal overwhelmingly dealt with offences such as robbery, banditry and theft rather than with purely social crimes, such as homicides, assaults or sexual offences. Colin MacLachlan, who studied this Criminal Justice institution, concluded "the interests of the state and such individuals coincided [... With the investment of relatively insignificant state funds to provide an organizational structure for the volunteer agents, the vice regal government demonstrated its ability to confine criminal activity throughout New Spain to an acceptable level. ${ }^{86}$ In other words, much of the legal system was outsourced to parallel institutions e.g. the court of the consulados, which dealt with commercial matters, the Tribunal of the Acordada or the Indian courts.

\section{Spanish Imperial Rule Revisited}

The political economy of the Spanish Empire was not what the textbook still tells us. Studies of revenue collection have shown that there was very little centralizing tendency and extraction to the metropolis was limited. At the same time local initiative, bargaining and control determined also much of the expenditure policies. The way in which the fiscal system was organised suggests that economic historian's singleminded focus on rulers who allegedly maximised revenue over all other things is mistaken. The structure of the Spanish fiscal administration over three centuries is not compatible with such a strategy. Instead it looks perfectly rational if we assume that the Spanish Crown tried to maximise aggrandisement of the Empire and the retention of the imperial bond

\footnotetext{
${ }^{86}$ C.M MacLachlan, Criminal Justice in Eighteenth Century Mexico. A Study of the Tribunal of the Acordada (Berkeley: University of California Press, 1974), 109.. Not surprisingly $71 \%$ of those who were before the Tribunal were of Spanish and Mestizo origin and only $29 \%$ classified as Indians. The Sala del Crimen, a similar tribunal which depended on the Audiencia, processed 39\% of Indians and $61 \%$ of Spanish and mestizos. Table 4 p 116.
} 
rather than simple income. This allowed it to acquire further rents while keeping the cost of running the empire very low.

The price of this strategy was the need to co-opt colonial elites. The means of co-optation was to keep most of the revenues in the Americas and allow local merchants a significant stake in their collection and expenditure. Intra-colonial transfers were the means to involve a large number of stakeholders in the system. Main local sectors received direct subsidies and merchants profited from the returns to the implicit credit. This 'hidden' credit market in turn served the states needs successfully in the sense that the empire could be maintained, run and defended for three centuries without disbursements from the metropolis. But the downside was the lack of a transparent interest rate and the underdevelopment of financial markets.

Still the system was clearly compatible with substantial economic growth in the $18^{\text {th }}$ century and it could be argued that it was inherently geared towards subsidising the most successful economic sectors. Seen from the working of the fiscal system and more specifically the way in which the Spanish Empire spent its money there is very little evidence for coercion or for a predatory state. It was a cheap way of running an Empire and the rule was very efficient in the sense that there were nearly no direct challenges towards Spanish rule from within. While Britain became more and more a shareholder society, where subjects could profit from government activities by buying bonds and shares, Spanish rule was based on a stakeholder concept, that co-opted its subjects through private-public-partnership deals that increased local participation and returns while necessarily circumscribing the power of the Crown to enforce any centralist designs.

Spanish and Spanish American subjects were deeply invested in imperial governance. The lack of a centralized fiscal system not only provided for local and regional bargaining in raising revenue, as has been 
argued before. It also gave colonial subjects a large influence over how, where and what the money was spent on. This took three main forms. Firstly, civilian expenditure on local administration, wages and purchases of goods was evidently a much larger share of outlays in the Spanish Empire than in Britain or France converting large numbers of merchants, bureaucrats and producers into imperial stakeholders. Within the system religious institutions and other corporate bodies performed as financial intermediaries, increasing in turn their stake in the colonial economy. Secondly, because military expenditure was raised and spent locally rather than centrally, it reinforced the same structures. Militias depended for their salaries on Spanish American cajas. Local suppliers were paid out of the same funds.

A side effect of this arrangement was the creation of a military apparatus that was wholly unsuitable for the suppression of any internal opposition to the empire. At the same time, it worked surprisingly well to repel external threats, such as Captain Vernon's 4000 men strong invasion of Cartagena during the War of Jenkins' Ear, or the brief occupation of Manila during the Seven Years war led by Admiral Cornish, or the equally ill fated attempts of the English navy on Buenos Aires 1806-1807. ${ }^{87}$ Overall, subjects of the Spanish Crown in the Americas were consistently unwilling to be 'liberated' by the British or anyone else. This leads to our third point. In order to keep expenditure low, the Crown allowed (or did little to avoid) additional jurisdictional fragmentation to

\footnotetext{
${ }^{87}$ British forces landed and eventually occupied these main ports - all them were main destinations of ICT throughout the $18^{\text {th }}$ century and destination point of million of silver pesos. Despite substantial numeric and warfare technological superiority local militias managed to contain or expel invaders very quickly. On September 1754 Brigadier General Draper led 6,389 men to Manila which was defended by 20 companies of 100 men each." These companies were far from being at full strength. Mortality, desertion and various detachments had reduced this regiment to some 565 soldiers. There were only 80 artillerymen, including some Filipinos." A renewed attempt in 1762 to take Cuba involved a 4,000 expedition directly from Portsmouth which occupied the city but could not hold in control as Cuban militias resisted. R Gott, Cuba, a New History (New Haven: Yale University Press, 2004), 39-41.
} 
result from devolving important judicial functions to corporate bodies and indigenous communities. In this way, it could combine a weak repressive apparatus with the upholding of imperial (devolved) rule.

Resistance to metropolitan aims was obviously not something special to the Spanish Empire. The recent historiography of anticolonialism is all about agency of and resistance from colonial populations, be they indigenous, colonials, slaves or criollos. ${ }^{88}$ Problems resulting from poor infrastructure and communications marred efficient and effective control in Dutch Java, Portuguese Brazil, or British North America. The interests of Europeans in the colonies were less and less aligned with those of their metropolitan peers as time went on. Yet, the perceived ineptitude of the centre to rule in the colonial peripheries of the Spanish Empire was not simply the result of a common 'technological' problem of running early modern European Empires or the emergence and consolidation of colonial identities as separate and autonomous. ${ }^{89}$ Spanish American subjects were used to running their own show, not as participants in local representative assemblies and shareholders of the state but as stakeholders in the empire's administration, defence and upholding of justice. That was why they opposed the attempts of $18^{\text {th }}$ century Bourbon reformers to over-rule local decision-makers so vehemently. They were a potential breach of the political and economic contract between colonial subjects and Crown in place for 250 years. They were successfully resisted and/or neutralized because the Crown had no means to push them through against those who essentially

\footnotetext{
${ }^{88}$ See e.g. Sergio Serulnikov, Subverting Colonial Authority: Challenges to Spanish Rule in Eighteenth-Century Southern Andes (Durham: Duke University Press, 2003).; Sinclair Thomson, "'We Alone Will Rule ...": Recovering the Range of Anticolonial Projects among Andean Peasants (La Paz 1740s to 1781)," Colonial Latin American Review 8 (1999).; Florencia E. Mallon, Peasant and Nation : The Making of Postcolonial Mexico and Peru (Berkeley: University of California Press, 1995).; Steve J. Stern, Resistance, Rebellion, and Consciousness in the Andean Peasant World, 18th to 20th Centuries (Madison Wis: University of Wisconsin Press, 1987).

${ }^{89}$ Irigoin and Grafe, "Bargaining for Absolutism."
} 
constituted the devolved and jurisdictionally fragmented state in the Americas.

Finally our analysis of Spanish governance marks some interesting contrasts with existing political economy models of the evolution of the fiscal state in monarchical regimes more generally. Economic historians of France have argued that a division of control between crown and elite over revenues on the one hand and royal control over expenditures on the other led to a blocking of fiscal reform and financial development in $18^{\text {th }}$ century France. ${ }^{90}$ The Spanish stakeholder empire chose a different path and avoided the potential stand-off by allowing elites a much larger share of control over expenditure as well. Monarchical regimes could evidently develop into more than one model of governance and fiscal systems. This is not to say political regimes did not matter at all in pre$18^{\text {th }}$ century Europe. But given the evidence that absolutists were constrained on the revenue side by jurisdictional fragmentation and at least in Spain also on the expenditure side by stakeholder rights, it is increasingly difficult to portray formal political regimes as the one factor that split the winners from the losers in the race of the institutional foundations of superior economic growth.

\footnotetext{
${ }^{90}$ Hoffman and Rosenthal, "Political Economy.", Rosenthal, "Political Economy." Francois Velde and David R. Weir, "The Financial Market and Government Debt Policy in France, 1746-1793," Journal of Economic History 52, no. 1 (1992): 6.
} 


\section{Appendix 1}

The data for the analysis of the treasury districts are derived from the accounts transcribed and published by J.J. TePaske and H. Klein, available in print as TePaske, John Jay, and Herbert S. Klein. The Royal Treasuries of the Spanish American Empire: Duke University Press, 1982 and online. The geographical area covered includes the Viceroyalties of Rio de la Plata and Peru, as well as New Spain. Missing is data for New Granada, today's Colombia, Venezuela and Central America. Data cover the entire colonial period, but there are many more missing accounts for individual districts in earlier periods than in later ones. For our samples, the relatively few missing observations are generally not for major treasury districts.

The choice of time periods was based on considerations of quality of data and historical events. An earlier sample would have been desirable, but survival of the data was such that the consistency of the results would have been suspect. The three periods 1729-33, 1785-89 and 1796-1800 are either long before or a number of years after the uprisings in Upper Peru that seriously affected tax collection. They cover the period of firstly the early (1729-33) and then the major impact of Bourbon Reforms (after 1785), and are prior to the conflicts that led to independence. The third sample reflects increasing pressures for revenue in a period of war.

For the earliest five-year period some of the accounts ran from April to March, others from January to December, still others covered more or less than one year. We treated April 1729 to March 1730 as the calendar year 1729. Since all calculations are based on five year intervals, we believe that the error resulting from this procedure is minimal. For a few cajas we had to average lump sums available for a longer period. That is especially true for Buenos Aires 1728 - 1733, where we had only overall 
amounts for six years 1728-1733. Again since we use five year averages the impact ought to be very small. In all calculations we only used the data available, i.e. we did not interpolate missing years. The reason for this procedure is that at times it is not clear if especially in smaller cajas data is lost or books were only updated irregularly. In addition, in some districts changes from year to year are too large to consider interpolation a possibility. Luckily, as mentioned above only small districts are affected.

We first determined net expenditures for each caja and each year, subtracting all entries that related to carry-overs and deposits from our net totals. We then re-classified every item for each caja to analyse the composition. Our category 'ICTs' only includes payments to other treasury districts in the colonies, those to the metropolis are identified as 'to Spain'. At times the destination treasury of transfers is clearly identified, but often it is just registered as going to 'other districts'. Thus it is impossible closely to follow the money trail through the districts. Table 9 below shows the outcome and structure of ICTs by caja for each of the five-year periods. Data for individual years are available upon request.

We also reclassified every single expenditure item according to the categories employed, i.e. military and civilian wage and non-wage and financial expenditure (table 5) and mining, tobacco, wages, goods and services, welfare and public works and collection costs (table 6). A detailed list of the several hundred different concepts subsumed in these categories is available upon request. Overall levels and trends of revenue, expenditure and transfers to Spain are summarised below in table 8. Comparable numbers for ICTs are shown in table 3 in the text. 
Table 8 Total revenues and transfers to Spain

\begin{tabular}{||l|c|r|r||}
\hline \hline & $1729-33$ & \multicolumn{1}{|c||}{$1785-89$} & \multicolumn{1}{|c||}{$1796-1800$} \\
\hline Total revenue pesos & $50,394,431$ & $255,194,445$ & $413,710,965$ \\
\hline $\begin{array}{l}\text { Annual growth rate of revenue \% } \\
\text { since previous period }\end{array}$ & & 2.9 & 4.5 \\
\hline Total expenditure pesos & $52,145,319$ & $220,817,011$ & $384,517,409$ \\
\hline $\begin{array}{l}\text { Annual growth rate of } \\
\text { expenditure \% }\end{array}$ & & 2.6 & 5.2 \\
\hline Transfers to Spain pesos & $5,548,888$ & $11,791,137$ & $21,591,802$ \\
\hline $\begin{array}{l}\text { Annual growth rate of transfers to } \\
\text { Spain \% }\end{array}$ & & 1.4 & 5.7 \\
\hline
\end{tabular}

Table 9 ICTs as percentage of total expenditure 1729-1733

\begin{tabular}{|c|c|c|c|}
\hline & $\begin{array}{r}\text { ICT share of } \\
\text { EXP \% } \\
\end{array}$ & $\begin{array}{r}\text { ICT share of } \\
\text { EXP \% } \\
\end{array}$ & $\begin{array}{r}\text { ICT share of } \\
\text { EXP \% } \\
\end{array}$ \\
\hline & $1729-1733$ & 1785-89 & $1796-1800$ \\
\hline \multicolumn{4}{|l|}{ Caja } \\
\hline \multicolumn{4}{|l|}{ Alto Peru } \\
\hline Arica & n.a. & 82.03 & 68.74 \\
\hline Carangas & 61.54 & 45.08 & 49.81 \\
\hline Charcas & not yet created & 18.23 & 0.00 \\
\hline Chucuito & 87.49 & 37.85 & 63.21 \\
\hline Cochabamba & not yet created & 6.49 & n.a. \\
\hline La Paz & 57.53 & 30.48 & 41.59 \\
\hline Oruro & 80.18 & 59.98 & 41.32 \\
\hline Potosi & 0.00 & 61.63 & 66.61 \\
\hline $\begin{array}{l}\text { Sta Cruz de la } \\
\text { Sierra }\end{array}$ & not yet created & 0.00 & 0.00 \\
\hline \multicolumn{4}{|l|}{ Chile } \\
\hline Chiloe & not yet created & 51.23 & 2.83 \\
\hline Concepcion & n.a. & 0.00 & 0.00 \\
\hline Mendoza & not yet created & 1.35 & 6.68 \\
\hline Stgo de Chile & 5.47 & 10.16 & 0.00 \\
\hline Valdivia & not yet created & 1.74 & 4.50 \\
\hline Rio de la Plata & & & \\
\hline
\end{tabular}




\begin{tabular}{|c|c|c|c|}
\hline Buenos Aires & 44.46 & 9.06 & 7.68 \\
\hline Catamarca & not yet created & 34.38 & 0.00 \\
\hline Cordoba & not yet created & 2.55 & 7.76 \\
\hline Corrientes & not yet created & 0.00 & 21.61 \\
\hline La Rioja & not yet created & 13.65 & 29.39 \\
\hline Maldonado & not yet created & 1.14 & 0.00 \\
\hline Montevideo & not yet created & 19.26 & 7.61 \\
\hline Paraguay & not yet created & 0.00 & 0.00 \\
\hline Salta & not yet created & 0.00 & 0.00 \\
\hline San Juan & not yet created & 42.30 & 0.00 \\
\hline Sta Fe & not yet created & 17.18 & 33.69 \\
\hline Stgo del Estero & not yet created & 0.00 & 0.00 \\
\hline Tucuman & not yet created & 0.00 & 26.21 \\
\hline \multicolumn{4}{|l|}{ Peru } \\
\hline Arequipa & 67.60 & 44.50 & 74.43 \\
\hline Cailloma & 92.10 & Abolished & abolished \\
\hline Carabaya & 19.34 & 17.47 & 79.32 \\
\hline Cuzco & 0.00 & 11.85 & 43.76 \\
\hline Huamanga & not yet created & 0.95 & 59.66 \\
\hline Huancavelica & 0.00 & n.a & n.a. \\
\hline Jauja & 65.87 & 82.01 & n.a. \\
\hline Lima & 11.93 & 9.86 & 11.39 \\
\hline Piura y Paita & 23.75 & Abolished & abolished \\
\hline Sana & 0.00 & Abolished & abolished \\
\hline Vico y Pasco & 82.20 & 59.62 & 68.16 \\
\hline \multicolumn{4}{|l|}{ Ecuador } \\
\hline Guayaquil & 0.00 & 62.06 & 17.32 \\
\hline Loja y Cuenca & 70.89 & 73.58 & 64.84 \\
\hline Quito & 37.68 & 23.30 & 34.95 \\
\hline Trujillo & 52.72 & 64.79 & 51.13 \\
\hline \multicolumn{4}{|l|}{ New Spain } \\
\hline Acapulco & 54.06 & 63.70 & 40.33 \\
\hline Arispe & not yet created & 46.23 & 83.54 \\
\hline Bolanios & not yet created & 65.25 & 85.57 \\
\hline Campeche & 75.15 & 11.74 & 26.28 \\
\hline Chihuahua & not yet created & 93.80 & 83.39 \\
\hline Durango & 95.37 & 54.58 & 90.98 \\
\hline Guanajuato & 97.08 & 90.47 & 90.25 \\
\hline Merida & 1.42 & 0.11 & 12.85 \\
\hline
\end{tabular}




\begin{tabular}{|l|r|r|r|}
\hline Mexico & 0.00 & 32.99 & 24.23 \\
\hline MGuadalajara & 79.16 & 68.60 & 86.44 \\
\hline Michoacan & not yet created & 0.00 & 4.60 \\
\hline MRosario & not yet created & 75.61 & 92.81 \\
\hline Oaxaca & not yet created & Not yet created & 81.46 \\
\hline Pachuca & 59.08 & 84.85 & 97.95 \\
\hline $\begin{array}{l}\text { Presidio } \\
\text { Carmen }\end{array}$ & 0.00 & 0.00 & 27.85 \\
\hline Puebla & & & \\
\hline Saltillo & not yet created & 0.00 & 18.41 \\
\hline SLPotosi & 80.00 & 78.52 & 95.92 \\
\hline Sombrerete & 59.85 & 73.26 & 92.22 \\
\hline Tabasco & 68.76 & 34.75 & 96.82 \\
\hline Veracruz & 24.73 & 52.55 & 7.32 \\
\hline Zacatecas & 95.18 & 79.05 & 37.36 \\
\hline Zimapan & 74.98 & 89.68 & 58.28 \\
\hline
\end{tabular}




\section{Appendix 2}

Syndicated loans to the Real Hacienda in $18^{\text {th }}$ Century Mexico ${ }^{\mathrm{i}}$

\begin{tabular}{|c|c|c|c|c|c|c|c|}
\hline & $\#^{i 1}$ & Amount & Agent & Lender & Collateral & Interest & Remarks \\
\hline 1743 & & $1,000,000$ & & Consulado & $\begin{array}{l}\text { Future alcabalas } \\
\text { yield }\end{array}$ & $\begin{array}{l}\text { 'a } \\
\text { premio' }\end{array}$ & $1,200,000$ pesos gathered in two months $s^{\text {iii }}$ \\
\hline 1746 & & $1,000,000$ & & Consulado & $\begin{array}{l}\text { Future alcabalas } \\
\text { yield }\end{array}$ & & $\begin{array}{l}70 \% \text { from Consulado, } 30 \% \text { from independent } \\
\text { merchants }\end{array}$ \\
\hline 1763 & & $1,500,000$ & & Consulado & & 0 & Only 300,000 pesos subscribed ${ }^{i v}$ \\
\hline 1782 & 3 & $1,000,000$ & $\begin{array}{l}\text { Syndicated } \\
\text { Consulado }\end{array}$ & & averias & 5 & $\begin{array}{l}\text { Guaranteed "with revenues from Hacienda". } \\
\text { Subscribed within a week, } 475,000 \text { pesos from } 7 \\
\text { large Consulado merchants, } 172,000 \text { pesos from } \\
25 \text { individuals, } 353,000 \text { pesos from } 8 \text { ecclesiastic } \\
\text { corporations and } 1 \text { capellania (church funds) }\end{array}$ \\
\hline 1783 & 5 & 523,376 & & Public & $\begin{array}{l}\text { Mortgage on } \\
\text { tobacco rents }\end{array}$ & 5 & $88 \%$ from Guadalajar \& Durango \\
\hline 1782 & 4 & $1,000,000$ & $\begin{array}{l}\text { Syndicated } \\
\text { Tribunal de } \\
\text { Mineria }\end{array}$ & & $\begin{array}{l}\text { 4grs per silver } \\
\text { mark as sinking } \\
\text { fund }\end{array}$ & 5 & $\begin{array}{l}\text { From } 18 \text { individuals and corporations; shares } \\
\text { ranging from } 3,000 \text { pesos to } 200,000 \text { including } \\
110,000 \text { from the Banco de Avio. Three } \\
\text { individuals controibuted up to } 65 \% \text { of the total }\end{array}$ \\
\hline 1790 & 7 & $1,000,000$ & $\begin{array}{l}\text { Syndicated } \\
\text { Consulado }\end{array}$ & & averias & 5 & \\
\hline 1793 & 11 & $1,100,000$ & $\begin{array}{l}\text { Tribunal de } \\
\text { Mineria }\end{array}$ & & $\begin{array}{l}\text { 3grs per silver } \\
\text { mark as sinking } \\
\text { fund }\end{array}$ & 5 & Plus 10\% from Guanajuato miners \\
\hline 1793 & & $1,500,000$ & Syndicated & & averias & 5 & Of which: 186,000 pesos from 3 large Consulado \\
\hline
\end{tabular}

\footnotetext{
'Elaborated on data from G. Del Valle Pavon, "El Apoyo Financiero del Consulado" pp134-148.

ii Numbers from table in Appendix III

iii No reference to the interest rate. Pp. 135-36

${ }^{\text {iv }}$ Consulado requested to resume the Alcabala collection. P.137

${ }^{\vee}$ Consulado recovered the collection of Alcabala. By 1785 half of the load was redeemed and of the remainder 330,000 pesos, belonging to 6 merchants, was reinvested by the Consulado. P.140
} 


\begin{tabular}{|c|c|c|c|c|c|c|c|}
\hline & & & Consulado & & & $\begin{array}{l}2 \text { yrs } \\
\text { maturity }\end{array}$ & $\begin{array}{l}\text { merchants, } 164,000 \text { from } 14 \text { ecclesiastic } \\
\text { corporations, } 218,000 \text { pesos from the Audience } \\
\text { and the rest }(563,000 \text { pesos) from } 45 \text { individual } \\
\text { lenders }\end{array}$ \\
\hline 1794 & 12 & $1,000,000$ & Syndicated & & averias & & $\begin{array}{l}\text { Of which: } 489,000 \text { pesos from religious and } \\
\text { civilian corporations, } 284,000 \text { pesos from } \\
\text { Consulado merchants and } 230,000 \text { pesos from } 39 \\
\text { rentiers }\end{array}$ \\
\hline 1809 & 21 & $3,000,000$ & $\begin{array}{l}\text { Syndicated } \\
\text { Consulados }\end{array}$ & & & 6 & Consulados of Mexico, Veracuz Guadalajara \\
\hline 1809 & 22 & $1,000,000$ & & $\begin{array}{l}\text { Private } \\
\text { Individuals }\end{array}$ & & free & $\begin{array}{l}15 \text { merchants, miners and landowners } \\
\text { contriibuted between } 20 \text { and } 20,000 \text { pesos and } 60 \\
\text { individuals for sums less than } 20,000 \text { pesos }\end{array}$ \\
\hline
\end{tabular}

\footnotetext{
vi Twelve of them were still creditors of Consulado in 1804. P.141

vii Subscribed within a week
} 


\section{Appendix 3:}

Treasury borrowing from Consulado de Mexico, $18^{\text {th }}$ century ${ }^{\mathrm{i}}$.

\begin{tabular}{|c|c|c|c|c|c|c|c|c|c|c|}
\hline Year & \# & Amount & & Lender/agent & Interest & Collateral & Benefits & Character & Remarks & Purpose \\
\hline $1781-84$ & 1 & 843,474 & $\mathrm{D}$ & Public ii & 0 & & & $\begin{array}{l}\text { King } \\
\text { request }\end{array}$ & donativo & \\
\hline $1781-82$ & 2 & $1,655,415$ & $\mathrm{~L}$ & merchants & 0 & & $\begin{array}{l}\text { Nobility } \\
\text { titles }^{\text {iii }}\end{array}$ & $\begin{array}{l}\text { Viceroy } \\
\text { request }\end{array}$ & $\begin{array}{l}\text { "suplemento" } \\
\text { debt } \\
\text { certificates } \\
(18)\end{array}$ & $\begin{array}{l}\text { War with } \\
\text { Britain in } \\
\text { Caribbean }\end{array}$ \\
\hline 1782 & 3 & $1,000,000$ & $\mathrm{~L}$ & Consuladoiv & 5 & $\begin{array}{l}\text { additional "4 al } \\
\text { millar" in } \\
\text { averia tax" }\end{array}$ & & $\begin{array}{l}\text { Viceroy } \\
\text { request }\end{array}$ & averia (2) & War UK \\
\hline 1782 & 4 & $1,000,000$ & $\mathrm{~L}$ & $\begin{array}{l}\text { Tribunal de } \\
\text { Mineriavi }^{2}\end{array}$ & 5 & $\begin{array}{l}\text { 4grs per silver } \\
\text { mark as } \\
\text { sinking fund }\end{array}$ & $\begin{array}{l}\text { Freeze on } \\
\text { quicksilver } \\
\text { imports }\end{array}$ & & & \\
\hline 1783 & 5 & 523,376 & $\mathrm{~L}$ & Public vii & 5 & $\begin{array}{l}\text { Mortgage on } \\
\text { tobacco rents }\end{array}$ & & $\begin{array}{l}\text { King } \\
\text { request }\end{array}$ & $\begin{array}{l}88 \% \text { from } \\
\text { Durango \& } \\
\text { Guadalajara }\end{array}$ & $\begin{array}{l}\text { War } \\
\text { expenses in } \\
\text { Cuba }\end{array}$ \\
\hline 1786 & 6 & 150,000 & $\mathrm{~L}$ & Consulado & 5 & $\begin{array}{l}\text { averia "4 al } \\
\text { millar" }\end{array}$ & & & $\begin{array}{l}\text { infrastructure } \\
\text { and grain }\end{array}$ & $\begin{array}{l}\text { agrarian } \\
\text { crisis }\end{array}$ \\
\hline 1790 & 7 & 100,000 & $\mathrm{~L}$ & Consulado & 5 & $\begin{array}{l}\begin{array}{l}\text { averia "5 al } \\
\text { millar" }\end{array} \\
\end{array}$ & & $\begin{array}{l}\text { Royal } \\
\text { request }\end{array}$ & & \begin{tabular}{|l} 
Peace with \\
Argel \\
\end{tabular} \\
\hline 1793 & 8 & 460,714 & $\mathrm{D}$ & Public $^{\text {viii }}$ & 0 & & & $\begin{array}{l}\text { King } \\
\text { request }\end{array}$ & $\begin{array}{l}\text { donativo } 10 \\
\text { years } \\
\text { maturity[12] }\end{array}$ & $\begin{array}{l}\text { war with } \\
\text { France }\end{array}$ \\
\hline $1793-94$ & 9 & $1,559,000$ & $\mathrm{~L}$ & $\begin{array}{l}\text { Consulado \& } \\
\text { Tribunal } \\
\text { Mineria } \\
\end{array}$ & 0 & Billls & & $\begin{array}{l}\text { King } \\
\text { request }\end{array}$ & $\begin{array}{l}6 \text { to } 8 \text { million } \\
\text { expected, } 2 \\
\text { years maturity }\end{array}$ & War \\
\hline 1793 & 10 & $1,000,000$ & $\mathrm{~L}$ & Consulado $^{\mathrm{IX}}$ & 5 & $\begin{array}{l}\text { Additional "5 al } \\
\text { millar" in } \\
\text { averia }\end{array}$ & & $\begin{array}{l}\text { Viceroy } \\
\text { request }\end{array}$ & & $\begin{array}{l}\text { war with } \\
\text { France }\end{array}$ \\
\hline 1793 & 11 & $1,100,000$ & $\mathrm{~L}$ & Tribunal & 5 & 3 grs per silver & & Viceroy & $10 \%$ from & War \\
\hline
\end{tabular}




\begin{tabular}{|c|c|c|c|c|c|c|c|c|c|c|}
\hline & & & & Mineria & & $\begin{array}{l}\text { mark as } \\
\text { sinking fund }\end{array}$ & & request & $\begin{array}{l}\text { Guanajuato } \\
\text { miners }\end{array}$ & \\
\hline 1794 & $12 \mathrm{a}$ & $1,000,000$ & $\mathrm{~L}$ & Consulado $^{x}$ & 5 & & & & & War \\
\hline 1794 & $12 b$ & $1,000,000$ & $\mathrm{~L}$ & $\begin{array}{l}\text { Tribunal de } \\
\text { Mineria }\end{array}$ & 5 & $\begin{array}{l}3 \text { grs per silver } \\
\text { mark at Mint } \\
\text { House as } \\
\text { sinking fund }\end{array}$ & & & & \\
\hline 1795 & 13 & 701,522 & $\mathrm{D}$ & Public ${ }^{x i}$ & 0 & & & $\begin{array}{l}\text { Viceroy } \\
\text { request }\end{array}$ & $\begin{array}{l}1 \text { millon } \\
\text { expected (9) }\end{array}$ & $\begin{array}{l}\text { war with } \\
\text { France }\end{array}$ \\
\hline 1798 & 15 & $1,618,914$ & $\mathrm{D}$ & Public & 0 & & & $\begin{array}{l}\text { Royal } \\
\text { request }\end{array}$ & $\begin{array}{l}\text { over } 3 \text { years } \\
\text { from request }\end{array}$ & \\
\hline 1798 & 14 & 500,000 & $\mathrm{D}$ & $\begin{array}{l}\text { Tribunal de } \\
\text { Mineria xii }\end{array}$ & 0 & $\begin{array}{l}3 \text { grs per silver } \\
\text { mark at Mint } \\
\text { House sinking } \\
\text { fund }\end{array}$ & & $\begin{array}{l}\text { Royal } \\
\text { request }\end{array}$ & $\begin{array}{l}\text { borrowed from } \\
\text { church funds } \\
\text { of } \\
\text { Mexico City } \\
\text { Archbishopry }\end{array}$ & $\begin{array}{l}\text { Complete } \\
\text { donation \# } \\
15\end{array}$ \\
\hline 1795-1802 & 16 & $7,172,264$ & L & $\begin{array}{l}\text { Consulado \& } \\
\text { Tribunal de } \\
\text { Mineria }\end{array}$ & 5 & $\begin{array}{l}\text { Mortgage on } \\
\text { tobacco rents }\end{array}$ & & $\begin{array}{l}\text { Viceroy } \\
\text { request }\end{array}$ & & \\
\hline 1798 & 17 & 496,366 & $\mathrm{~L}$ & Public ${ }^{\text {xiv }}$ & Free & $\begin{array}{l}\text { Bonds \& } \\
\text { shares }\end{array}$ & & $\begin{array}{l}\text { Royal } \\
\text { request }\end{array}$ & $\begin{array}{l}\text { "Patriotic loan" } \\
10 \text { years } \\
\text { Maturity [12] }\end{array}$ & War with UK \\
\hline 1805 & 18 & 497,557 & $\mathrm{D}$ & Public $^{x V}$ & Free & & & & & \\
\hline $1805-1808$ & $\begin{array}{l}19 a \\
19 b\end{array}$ & $\begin{array}{r}9,571,800 \\
750,000\end{array}$ & $\begin{array}{l}\mathrm{L} \\
\mathrm{L}\end{array}$ & $\begin{array}{l}\text { Religious } \\
\text { corporations } \\
\text { Indigenous } \\
\text { communities }\end{array}$ & 3 & & $\begin{array}{l}\text { Consolidaci } \\
\text { on Vales } \\
\text { Reales } \\
\text { lbid xvii }\end{array}$ & & $\begin{array}{l}\text { Consolidacion } \\
\text { vales reales, } \\
\text { Sales of state } \\
(14)\end{array}$ & \\
\hline 1805 & 20 & 23,754 & $\mathrm{D}$ & $\begin{array}{l}\text { Mexico City } \\
\text { Public }^{\text {xviii }}\end{array}$ & Free & & $\begin{array}{l}\text { List of } \\
\text { contributors } \\
\text { made public }\end{array}$ & & & \\
\hline $1808-1810$ & 21 & $1,941,643$ & $\mathrm{D}$ & Public & & & $\begin{array}{l}\text { List of } \\
\text { contributors } \\
\text { made public }\end{array}$ & $\begin{array}{l}\text { Viceroy } \\
\text { request }\end{array}$ & $\begin{array}{l}450,000 \\
\text { collected } \\
\text { within } \\
\text { the first month }\end{array}$ & $\begin{array}{l}\text { War against } \\
\text { French } \\
\text { occupation }\end{array}$ \\
\hline 1809 & 21 & $3,176,835$ & $\mathrm{~L}$ & Consulados & 6 & escritura de & & Royal & 5 years & French \\
\hline
\end{tabular}




\begin{tabular}{|l|l|l|l|l|l|l|l|l|l|l|}
\hline & & & & $\begin{array}{l}\text { of Mexico, } \\
\text { Veracruz \& } \\
\text { Guadalajara }\end{array}$ & & riesgo (bond) & & request & maturity \\
\hline 1809 & 22 & $1,000,000$ & $\mathrm{~L}$ & $\begin{array}{l}\text { private } \\
\text { individuals }\end{array}$ & Free & & & $\begin{array}{l}\text { Viceroy in } \\
\text { request }\end{array}$ & $\begin{array}{l}\text { gathered } \\
\text { among } \\
\text { wealthiest } \\
\text { residents(19) }\end{array}$ & $\begin{array}{l}\text { fight French } \\
\text { occupation }\end{array}$ \\
\hline
\end{tabular}

'Own elaboration from C. Marichal, Bankruptcy of Empire. Mexican Silver and the Wars between Spain, Britain and France, 1780-1810. Appendix III pp.276-286 and table 8.3 pp. 244.

i Donation: $75 \%$ from indigenous \& castas plus large noble merchants and 55 big proprietors

iii from 47 merchants of Mexico City, 19 from Xalapa and 15 from the port of Veracruz

${ }^{i v}$ As financial agent: funds from seven Consulado members, two independent merchants, seven rentiers from Mexico City and nine religious corporations.

$\checkmark$ "Four to the thousand" ad valorem tax of 0.5 per cent charged on overseas trade (averia) which subsequently was collected by the Consulado (averia hereafter)

${ }^{v i}$ As financial agent: shares ranging from 3,000 pesos to 200,000 including 110,000 from the Banco de Avio. Three individuals contributed up to 65 $\%$ of the total.

vii $88 \%$ of it came from Durango \& Guadalajara.

viii Donation: $50 \%$ from towns and villages. The rest provided by big proprietors, ecclesiastic corporations and cabildos.

${ }^{\text {ix }}$ as Agent, funds gathered within 3 months

${ }^{x}$ As financial agent: funds from 6 Consulado members, 13 independent merchants and 19 religious corporations. Largest individual share totaled $\$$ 200,000 .

${ }^{x i}$ Only $70 \%$ of the requested amount raised.

${ }^{x i i}$ Funds borrowed from Church funds Censos Y Capellanias belonging to Archbishop of Mexico City

xiii As financial agents: of 15 mio expected by the Crown. Viceroy requested 3 mio from each Corporations

xiv The viceroy contributed with 15,000 pesos and Consulado paid 100,000 pesos. Most of funds were large contribution from merchants, and religious corporations; total 8,162 shares of 50 pesos each. List of contributors made public "To raise the vanity more than the patriotism of those who have money to subscribe the loan".

${ }_{x v}$ Tribunal de Mineria lent 500,000 pesos, Consulado 50,000 pesos and "senores Obispos" (Bishops) furnished 100,000 pesos

xvi Government paid interest regularly. Principal was never recovered

xvii Loan transformed in a donation in 1809 but government paid interests at times. Principal was never recovered

xviii "Overwhelmingly small donations"

${ }^{\text {xix }}$ within a week 15 merchants, miners \& landowners contributed between 20 and 200,000 pesos and 60 individuals for sums less than 20,000 pesos 


\section{Appendix 4:}

Treasury borrowing from Consulado de Lima, 18th century.

\begin{tabular}{|c|c|c|c|c|c|c|c|c|}
\hline$\underline{\#}$ & Year & Amount & $\mathrm{D} / \mathrm{L}^{\mathrm{iI}}$ & Interest & Collateral & Character & Remarks & Purpose \\
\hline 1 & 1709 & 20,000 & $\mathrm{D}$ & $\begin{array}{l}\text { "sin } \\
\text { premio" }\end{array}$ & & & $\begin{array}{l}\text { Pro-rate among } \\
\text { merchants }\end{array}$ & $\begin{array}{l}\text { War with England, } \\
\text { ships }\end{array}$ \\
\hline 2 & 1711 & Unspecified & $\mathrm{D}$ & Consulate & & Requested & unsubscribed & Defense and escort of Fleet to Spain \\
\hline 3 & 1717 & 20,000 & $\mathrm{D}$ & & & & $\begin{array}{l}\text { Pro-rate } \\
\text { voluntary }\end{array}$ & Defense Callao from French privateers \\
\hline 4 & 1722 & 100,000 & $\mathrm{D}^{\mathrm{iii}}$ & & & & & Fitting 2 war ships \\
\hline 5 & 1724 & 200,000 & $\mathrm{D}$ & & $\begin{array}{l}\text { Advance on } \\
\text { future taxes }\end{array}$ & $\begin{array}{l}\text { Advance of } \\
\text { treasury } \\
\text { funds }\end{array}$ & unsubscribed & Fitting 2 galleons \\
\hline 6 & 1724 & 3,932 & $\mathrm{D}$ & gracioso $^{\text {iv }}$ & & & & Arms for galleons \\
\hline 7 & 1725 & Unspecified & $\mathrm{D}$ & & & $\begin{array}{l}\text { Treasury } \\
\text { Request }\end{array}$ & refused & $\begin{array}{l}\text { Fitting a war ship to capture French } \\
\text { pirates }\end{array}$ \\
\hline 8 & 1729 & 200,000 & $\mathrm{D}$ & & & $\begin{array}{l}\text { Treasury } \\
\text { Request }\end{array}$ & Partial & "Crown needs", 1 million requested \\
\hline 9 & 1732 & 55,521 & $\mathrm{D}$ & & $\begin{array}{l}5 \% \text { on silver } \\
\text { shipped to } \\
\text { Portobello }\end{array}$ & $\begin{array}{l}\text { to be paid in } \\
\text { Portobello }^{v}\end{array}$ & & Relocation of Portobello city \\
\hline 10 & 1734 & 300,000 & $\mathrm{D}$ & & & $\begin{array}{l}\text { Viceroy } \\
\text { request }\end{array}$ & Unsubscribed & $\begin{array}{l}\text { Fitting a warship to chase Dutch } \\
\text { privateers }\end{array}$ \\
\hline 11 & 1739 & 100,000 & $\mathrm{~L}$ & & $\begin{array}{l}\text { Collection of } \\
\text { derrama \& } \\
\text { averia taxes }\end{array}$ & $\begin{array}{l}\text { Royal } \\
\text { cedula }\end{array}$ & & Defense of Panama \\
\hline 12 & 1738 & 200,000 & $\mathrm{D}$ & & $\begin{array}{l}\text { 1.5\% on } \\
\text { Armada' } \\
\text { funds }^{\text {vi }}\end{array}$ & $\begin{array}{l}\text { Requested } \\
\text { in } 1734\end{array}$ & & Relocation of Portobello \\
\hline 13 & 1740 & 300,000 & $\mathrm{D}$ & $3 \%$ & & $\begin{array}{l}\text { Viceroy } \\
\text { request }\end{array}$ & $\begin{array}{l}\text { raised among } \\
\text { individual } \\
\text { merchants }\end{array}$ & Defense of viceroyalty \\
\hline
\end{tabular}




\begin{tabular}{|c|c|c|c|c|c|c|c|c|}
\hline 14 & 1740 & 200,000 & $\mathrm{D}$ & gracioso & & Ibid & & \\
\hline 15 & 1740 & & D & & & Requested & unsubscribed $^{\text {vii }}$ & Fitting a warship \\
\hline 16 & 1740 & $\begin{array}{r}500,000 \\
\text { with } \\
\text { interests }\end{array}$ & $\mathrm{D}$ & $5 \%$ & & $\begin{array}{l}\text { Viceroy } \\
\text { request }\end{array}$ & $\begin{array}{l}\text { raised among } \\
\text { individual } \\
\text { merchants }^{\text {viii }}\end{array}$ & War with England \\
\hline 17 & 1740 & $\begin{array}{l}\text { "As much } \\
\text { as needed" } \\
\text { ix }\end{array}$ & $D^{x}$ & & & & & Fitting warship Capitana \\
\hline 18 & 1745 & 75,000 & $\mathrm{~L}$ & & $\begin{array}{l}\text { Advance of } \\
\text { taxes } 2 \% \text { on } \\
\text { silver and } \\
.5 \% \text { on gold } \\
\text { remittances }\end{array}$ & $\begin{array}{l}\text { Viceroy } \\
\text { request }\end{array}$ & & Fitting of 2 warships \\
\hline 19 & 1753 & 50,000 & $\mathrm{D}$ & gracioso & & $\begin{array}{l}\text { Viceroy } \\
\text { request }\end{array}$ & & Building of royal fort in Portobello \\
\hline 20 & 1762 & Unspecified & $\mathrm{D}$ & $\begin{array}{l}\text { "a } \\
\text { interes" }\end{array}$ & & $\begin{array}{l}\text { Viceroy } \\
\text { request }\end{array}$ & $\begin{array}{l}\text { raised among } \\
\text { individual } \\
\text { merchants } \\
\text { rejected by } \\
\text { members }\end{array}$ & To equip 1,000 strong troops in Lima \\
\hline 21 & 1763 & Unspecified & $\mathrm{D}$ & & $\begin{array}{l}\text { Additional } \\
\text { levy } 2 \% \text { on } \\
\text { silver and } 4 \\
\text { rls on gold } \\
\text { remittances }\end{array}$ & $\begin{array}{l}\text { Viceroy } \\
\text { request }\end{array}$ & & Expenses from War with England \\
\hline 22 & 1765 & 21,000 & $\mathrm{D}$ & gracioso & & & $\begin{array}{l}\text { Fewer than } \\
\text { expected } \\
\text { individual } \\
\text { subscriptions }\end{array}$ & Princess Ma Luisa's wedding \\
\hline 23 & 1765 & 50,000 & $\mathrm{D}$ & gracioso & & & $\begin{array}{l}\text { Complete } \\
\text { donativo \# } 22^{x i}\end{array}$ & ibid \\
\hline
\end{tabular}




\begin{tabular}{|c|c|c|c|c|c|c|c|c|}
\hline 24 & 1777 & $1,500,000$ & $\mathrm{~L}$ & & $\begin{array}{l}1 \% \text { on silver } \\
\text { and } .75 \% \text { on } \\
\text { gold } \\
\text { remittances }\end{array}$ & Royal order & $\begin{array}{l}\text { On silver } \\
\text { shipments from } \\
\text { Callao, Arica } \\
\text { and Guayaquil }\end{array}$ & Defense of Buenos Aires \\
\hline 25 & 1784 & $\begin{array}{r}2,000 \\
\text { annually }\end{array}$ & $\mathrm{D}$ & & $\begin{array}{l}\text { Advances on } \\
\text { averia tax } \\
\text { yield }^{\text {xiii }}\end{array}$ & $\begin{array}{l}\text { Royal } \\
\text { Cedula }\end{array}$ & & Council of Indias support \\
\hline 26 & 1780 & Unspecified & $\mathrm{D}$ & gracioso & & & & Equipment of 1,000 men army \\
\hline 27 & 1781 & $1,500,000$ & $\mathrm{~L}$ & & $\begin{array}{l}\text { 1\% on silver } \\
\text { and . } 75 \% \text { on } \\
\text { gold } \\
\text { remittances }\end{array}$ & & $\begin{array}{l}\text { On silver } \\
\text { shipments from } \\
\text { Montevideo and } \\
\text { Buenos Aires xiv }\end{array}$ & Repression of Tupac Amaru rebellion \\
\hline 28 & 1786 & 50,000 & $\mathrm{D}$ & gracioso & & & & Peace with Argel \\
\hline 29 & 1787 & $\begin{array}{r}2,000 \\
\text { annually }\end{array}$ & $\mathrm{D}$ & & & $\begin{array}{l}\text { Royal } \\
\text { Cedula } \\
\end{array}$ & & \\
\hline
\end{tabular}

'Own elaboration on date from Indice del Archivo del Tribunal del Consulado de Lima. (Lima, 1948) pp. 111-124,192 and 216

ii $D$ for Donation L for Loan.

iii "mas todo el dinero que se gaste"

iv Voluntary and no counterpart specified hereafter

${ }^{\vee}$ Transformed into a loan to Panama merchants at premium. A blaze in 1734 had destroyed main royal establishments in Portobello.

${ }^{v i} A$ charge on silver funds shipped in the regular journey of the fleet to Spain

vii Consulado alleged bad business climate and difficulties to gather funds "for which the averia contribution was collected" $\mathrm{p} 121$

viii As advance Consulado directed " to give 300,000 pesos as donation out of the silver and funds of Quito" p 121

ix "or appropriate 100,000 pesos belonging to Quito's representative". In May 1741 in order to refund the advance made by Quito the Consulado requested Viceroy approval to raise a loan among merchants. $\mathrm{p} 142$

x In 1742 a new tax "Nuevo Impuesto" was established to refund the 2 million pesos the treasury had spent in the War and commissioned the Consulado to collect the new tax. In 1747 there was a total of 460,000 pesos in arrears and the Consulado maintained the collection of the levy.

${ }^{x i}$ Spanish merchants and guilds requested royal exemption of the assigned contribution collected by Lima Consulado $p$ 123-24

xii Order by Council of India and Royal Cedula of $7^{\text {th }}$ July 1779

xiii Averia collection reinstate as Consulado prerogative.

xiv Order by Council of India Jose de Galvez and Royal Cedula of $9^{\text {th }}$ January 1785.

${ }^{x v}$ Extending previous donation (\# 28), "as in Mexico and Cadiz." 


\section{LONDON SCHOOL OF ECONOMICS}

\section{ECONOMIC HISTORY DEPARTMENT WORKING PAPERS}

(from 2005 onwards) For a full list of titles visit our webpage at

http://www.lse.ac.uk/

\section{5}

WP88 Labour Market Adjustment to Economic Downturns in the Catalan textile industry, 1880-1910. Did Employers Breach Implicit Contracts?

Jordi Domenech

WP89 Business Culture and Entrepreneurship in the Ionian Islands under British Rule, 1815-1864

Sakis Gekas

WP90 Ottoman State Finance: A Study of Fiscal Deficits and Internal Debt in 1859-63

Keiko Kiyotaki

WP91 Fiscal and Financial Preconditions for the Rise of British Naval Hegemony 1485-1815 Patrick Karl O'Brien

WP92 An Estimate of Imperial Austria's Gross Domestic Fixed Capital Stock, 1870-1913: Methods, Sources and Results Max-Stephan Schulze

2006

WP93 Harbingers of Dissolution? Grain Prices, Borders and Nationalism in the Hapsburg Economy before the First World War

Max-Stephan Schulze and Nikolaus Wolf

WP94 Rodney Hilton, Marxism and the Transition from Feudalism to Capitalism

S. R. Epstein

Forthcoming in C. Dyer, P. Cross, C. Wickham (eds.)

Rodney Hilton's Middle Ages, 400-1600 Cambridge UP 2007 
WP95 Mercantilist Institutions for the Pursuit of Power with Profit. The Management of Britain's National Debt, 1756-1815 Patrick Karl O'Brien

WP96 Gresham on Horseback: The Monetary Roots of Spanish American Political Fragmentation in the Nineteenth Century Maria Alejandra Irigoin

2007

WP97 An Historical Analysis of the Expansion of Compulsory Schooling in Europe after the Second World War Martina Viarengo

WP98 Universal Banking Failure? An Analysis of the Contrasting Responses of the Amsterdamsche Bank and the Rotterdamsche Bankvereeniging to the Dutch Financial Crisis of the 1920 s

Christopher Louis Colvin

WP99 The Triumph and Denouement of the British Fiscal State:

Taxation for the Wars against Revolutionary and Napoleonic France, 1793-1815.

Patrick Karl O’Brien

WP100 Origins of Catch-up Failure: Comparative Productivity Growth in the Hapsburg Empire, 1870-1910 Max-Stephan Schulze

WP101 Was Dick Whittington Taller Than Those He Left Behind? Anthropometric Measures, Migration and the Quality of life in Early Nineteenth Century London Jane Humphries and Tim Leunig

WP102 The Evolution of Entertainment Consumption and the Emergence of Cinema, 1890-1940 Gerben Bakker

WP103 Is Social Capital Persistent? Comparative Measurement in the Nineteenth and Twentieth Centuries Marta Felis Rota 
WP104 Structural Change and the Growth Contribution of Services:

How Motion Pictures Industrialized US Spectator Entertainment Gerben Bakker

WP105 The Jesuits as Knowledge Brokers Between Europe and China (1582-1773): Shaping European Views of the Middle Kingdom Ashley E. Millar

WP106 Regional Income Dispersion and Market Potential in the Late Nineteenth Century Habsburg Empire Max-Stephan Schulze

\section{8}

WP107 'The Big Problem of the Petty Coins', and how it could be solved in the late Middle Ages

Oliver Volckart

WP108 The Anglo-German Industrial Productivity Puzzle, 1895-1935: A Restatement and a Possible Resolution Albrecht Ritschl

WP109 The History, Nature and Economic Significance of an Exceptional Fiscal State for the Growth of the British Economy, 1453-1815

Patrick O'Brien

WP110 The Economic History of Sovereignty: Communal Responsibility, the Extended Family, and the Firm Lars Boerner and Albrecht Ritschl

WP111 A Stakeholder Empire: The Political Economy of Spanish Imperial Rule in America Regina Grafe and Alejandra Irigoin 